\title{
Basolateral Amygdala Neurons Maintain Aversive Emotional Salience
}

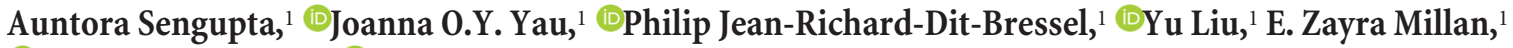 \\ John M. Power, ${ }^{2}$ and ${ }^{\circledR}$ Gavan P. McNally ${ }^{1}$ \\ ${ }^{1}$ School of Psychology and 2Department of Physiology and Translational Neuroscience Facility, School of Medical Sciences, University of New South Wales, \\ Sydney, 2052 New South Wales, Australia
}

BLA neurons serve a well-accepted role in fear conditioning and fear extinction. However, the specific learning processes related to their activity at different times during learning remain poorly understood. We addressed this using behavioral tasks isolating distinct aspects of fear learning in male rats. We show that brief optogenetic inhibition of BLA neurons around moments of aversive reinforcement or nonreinforcement causes reductions in the salience of conditioned stimuli, rendering these stimuli less able to be learned about and less able to control fear or safety behaviors. This salience reduction was stimulus-specific, long-lasting, and specific to learning about, or responding to, the same aversive outcome, precisely the goals of therapeutic interventions in human anxiety disorders. Our findings identify a core learning process disrupted by brief BLA optogenetic inhibition. They show that a primary function of the unconditioned stimulus-evoked activity of BLA neurons is to maintain the salience of conditioned stimuli that precede it. This maintenance of salience is a necessary precursor for these stimuli to gain and maintain control over fear and safety behavior.

Key words: amygdala; conditioning; fear; salience

\section{Significance Statement}

The amygdala is essential for learning to fear and learning to reduce fear. However, the specific roles served by activity of different amygdala neurons at different times during learning is poorly understood. We used behavioral tasks isolating distinct aspects of learning in rats to show that brief optogenetic inhibition of BLA neurons around moments of reinforcement or nonreinforcement disrupts maintenance of conditioned stimulus salience. This causes a stimulus-specific and long-lasting deficit in the ability of the conditioned stimulus to be learned about or control fear responses. These consequences are the precisely goals of therapeutic interventions in human anxiety disorders. Our findings identify a core learning process disrupted by brief BLA optogenetic inhibition.

\section{Introduction}

The capacity to learn about and respond to sources of danger in the environment is essential to survival. Within the laboratory, Pavlovian fear conditioning is most commonly used to model this learning. In conditioning, subjects, typically rats or mice,

\footnotetext{
Received Aug. 27, 2017; revised Oct. 11, 2017; accepted 0ct. 18, 2017

Author contributions: A.S., J.O.Y.Y., P.J.-R.D.B., E.Z.M., J.M.P., and G.P.M. designed research; A.S., J.O.Y.Y., P.J.R.D.B., and J.M.P. performed research; J.O.Y.Y., P.J.-R.D.B., and Y.L. contributed unpublished reagents/analytic tools; A.S., J.O.Y.Y., P.J.-R.D.B., Y.L., E.Z.M., J.M.P., and G.P.M. analyzed data; A.S., J.O.Y.Y., P.J.-R.D.B., E.Z.M., and G.P.M. wrote the paper.

This work was supported by Australian Research Council Grants DP170100075 and DP160100004 to G.P.M., and Australian Postgraduate Award to Y.L. Data are archived in the University of New South Wales Long Term Data Archive (ID: D0235272). We thank Kathryn Baker, Kelsey Zimmerman, Nathan Holmes, and Fred Westbrook for helpful discussions of these experiments.

The authors declare no competing financial interests.

Correspondence should be addressed to Dr. Gavan P. McNally, School of Psychology, University of New South Wales Sydney, 2052 New South Wales, Australia. E-mail: g.mcnally@unsw.edu.au.

DOI:10.1523/JNEUROSCI.2460-17.2017

Copyright $\odot 2018$ the authors $\quad 0270-6474 / 18 / 383001-12 \$ 15.00 / 0$
}

receive pairings of an initial neutral conditioned stimulus (CS) with an aversive unconditioned stimulus (US), such as footshock. A large body of work shows that the amygdala is essential for Pavlovian fear learning.

The amygdala contributes to both acquisition and expression of Pavlovian fear learning (Davis, 1992; Schafe et al., 2001; Maren and Quirk, 2004; Paré et al., 2004; Lüthi and Luscher, 2014). Within amygdala, CaMKII $\alpha$ principal neurons of the basolateral amygdala are especially important (Sah et al., 2003). These BLA neurons show plasticity during fear conditioning (McKernan and Shinnick-Gallagher, 1997; Maren and Quirk, 2004; Marek et al., 2013), are subject to complex regulation by multiple families of GABAergic interneurons (Ehrlich et al., 2009; Wolff et al., 2014; Tovote et al., 2015), and are robustly excited by aversive US, such as footshock (Wolff et al., 2014). This US-evoked activity is essential to causing fear learning. For example, brief optogenetic inhibition of BLA principal neurons during the shock US impairs fear learning (Wolff et al., 2014; Namburi et al., 2015). Moreover, 
excitation of BLA principal neurons during the US can augment fear learning (Johansen et al., 2014) and can serve as a US in its own right, supporting modest responding to a CS that signals such excitation (Johansen et al., 2010a; Gore et al., 2015).

However, the specific learning processes related to this USevoked activity and that are affected by optogenetic manipulation of BLA principal neurons during fear conditioning remain unknown. Fear learning involves multiple processes, and even the simple delivery or omission of a footshock US has many effects on learning. The primary learning-related functions of the shock US (i.e., reinforcement) or its absence (i.e., nonreinforcement) in fear conditioning are maintenance of CS salience enabling the CS to be learned about and responded to, contribution to a prediction error computation, and updating as well as storing the most recent aversive value of the CS (for review, see Hall and Rodríguez, 2017). BLA principal neurons may contribute to many of these functions. However, which functions are linked to their activity during aversive reinforcement and nonreinforcement remains poorly understood.

We addressed this by using adeno-associated viral vectors (AAVs) to express the inhibitory opsin eNpHR3.0 in BLA neurons and manipulating their activity during aversive reinforcement and nonreinforcement in Pavlovian fear conditioning. We examined the impact of optogenetic inhibition on fear learning, extinction learning, appetitive learning, safety learning, simple discrimination learning, and CS preexposure learning. We show that brief optogenetic inhibition during moments of aversive reinforcement or nonreinforcement renders a CS less able to be learned about and less able to control fear or safety behaviors. This salience reduction is stimulus-specific, long-lasting, and specific to learning about or responding to aversive outcomes.

\section{Materials and Methods}

Experimentally naive male Sprague Dawley rats (260-350 g), 8-9 weeks of age at the start of the experiments, were obtained from Animal Resources Centre (Murdoch, Western Australia). Animals were housed in groups of 4 in plastic cages in ventilated racks in a colony room maintained on a 12:12 light dark cycle (lights on 07:00). All experiments were conducted daily between 10:00 and 13:00 h. Food and water were freely available until $3 \mathrm{~d}$ before the start of behavioral training when rats were maintained on $65 \mathrm{~g}$ of standard laboratory chow (Gordon's Rat and Mouse Food) per day (in addition to any pellets earned) and continuous access to water.

\section{Apparatus}

All behavioral procedures were conducted in eight identical operant chambers with dimensions $24 \mathrm{~cm}$ (length) $\times 30 \mathrm{~cm}$ (width) $\times 21 \mathrm{~cm}$ (height). The top, rear wall, and hinged door of the chamber were constructed of Perspex. The sidewalls of the chamber were constructed of stainless-steel panels. All chambers had a grid floor constructed of stainless-steel rods, $4 \mathrm{~mm}$ in diameter spaced $15 \mathrm{~mm}$ apart. The grid floor was connected to a constant current generator. An external magazine hopper (measuring $5 \times 5 \mathrm{~cm}$ ) was built in to the left side panel and was attached to a pellet delivery system that delivered $45 \mathrm{~g}$ grain pellets (Able Scientific). A lever was mounted $4 \mathrm{~cm}$ to the right of the magazine hopper. Each chamber was placed in a larger sound-attenuating box with dimensions $59.5 \mathrm{~cm}$ (length) $\times 59 \mathrm{~cm}$ (width) $\times 48 \mathrm{~cm}$ (height). A fan was attached to the wall of the sound-attenuating box to provide ventilation during behavioral testing and a $28 \mathrm{~V}$ house light mounted on the rear wall of the operant chambers. An LED driver with integrated rotary joint ( $625 \mathrm{~nm}$ wavelength; Doric Instruments) was suspended above the operant chamber. The auditory CS were an $85 \mathrm{~dB} 10 \mathrm{~Hz}$ clicker and 1800 $\mathrm{Hz}, 85 \mathrm{~dB}$ tone delivered through a speaker attached to rear wall of the chamber. The visual CS were a $2 \mathrm{~Hz}$ flashing LED mounted outside the conditioning box on the roof of the sound-attenuating chambers and $28 \mathrm{~V}$ house light turning off. The US was a $0.6 \mathrm{~mA} 0.5 \mathrm{~s}$ scrambled footshock delivered to the grid floor. All behavioral protocols were controlled through Med-PC software (Med Associates).

\section{Viral vectors}

AAV vectors encoding eNpHR3.0 (AAV5-CaMKII $\alpha$-eNpHR3.0-WPREeYFP, $6 \times 10^{12} \mathrm{vp} / \mathrm{ml}$ ) or eYFP (AAV5-CaMKII $\alpha$-eYFP, $4 \times 10^{12} \mathrm{vp} / \mathrm{ml}$ ) were obtained from UNC Vector Core (University of North Carolina, Chapel Hill, NC), whereas AAVs encoding AAV5-CaMKII $\alpha$-GCaMP6fWPRE-SV40 $\left(4.25 \times 10^{13} \mathrm{vp} / \mathrm{ml}\right)$ were obtained from Penn Vector Core (University of Pennsylvania, Philadelphia).

\section{Stereotaxic surgery}

Before surgery, rats received an intraperitoneal injection of a mixture of $100 \mathrm{mg} / \mathrm{ml}$ ketamine (Ketapex, Apex Laboratories) and $0.3 \mathrm{ml} / \mathrm{kg}$ xylazine (Rompun; Bayer). Once anesthetized, rats were placed in a stereotaxic apparatus (Model 942, David Kopf Instruments) and shaved to expose the skin surface of the head. Before incision, rats received a subcutaneous injection of carprofen $(5 \mathrm{mg} / \mathrm{kg}$ ) and an injection of $0.5 \%$ bupivacaine (Cenvet) just under the surface of the incision site. Following incision, metal screws were positioned around the craniotomies and attached to the skull. A hand drill was then used to make two craniotomies above the BLA, and a $5 \mu \mathrm{l}, 30$-gauge conical tipped microinfusion syringe (Hamilton) was used to infuse $0.75 \mu \mathrm{l}$ of AAV vectors into BLA (from bregma, anteroposterior $-3.00 \mathrm{~mm}$; mediolateral $\pm 5.00 \mathrm{~mm}$; dorsoventral $-8.60 \mathrm{~mm}$ ) (Paxinos and Watson, 2007) over a $3 \mathrm{~min}$ period at a rate of $0.25 \mu \mathrm{l} / \mathrm{min}$ (UMP3 with SYS4 Microcontroller; World Precision Instruments). The syringe was left in place for 5-7 min to permit diffusion of the injected vectors. After viral infusion, fiber optic cannulae were lowered into the BLA (from bregma, anteroposterior $-3.00 \mathrm{~mm}$; mediolateral $\pm 5.00 \mathrm{~mm}$; dorsoventral $-7.50 \mathrm{~mm}$ for eNpHR3.0, $-8.31 \mathrm{~mm}$ for gCaMP6f) (Paxinos and Watson, 2007). These cannulae were held in place by dental cement anchored to the screws and the skull. After surgery, rats were injected intraperitoneally with $0.3 \mathrm{ml}$ of $300 \mathrm{mg} / \mathrm{ml}$ solution of procaine penicillin (Benicillin; Illium) and subcutaneously with $0.3 \mathrm{ml}$ of a $100 \mathrm{mg} / \mathrm{ml}$ solution of cephazolin (Hospira). Daily postoperative and recovery procedures, including weight and infection management, were conducted for the remainder of the experiment. All procedures commenced a minimum of 3 weeks after surgery.

\section{Electrophysiology}

Rats were deeply anesthetized with isoflurane (5\%), decapitated, and their brain rapidly removed and submerged in ice-cold oxygenated $(95 \%$ $\mathrm{O}_{2}, 5 \% \mathrm{CO}_{2}$ ) sucrose-modified ACSF, with the following composition (in mM): 124 sucrose, $62.5 \mathrm{NaCl}, 2.5 \mathrm{KCl}, 26 \mathrm{NaHCO}_{3}, 1.2 \mathrm{NaH}_{2} \mathrm{PO}_{4}, 10$ glucose, $0.5 \mathrm{CaCl}_{2}$, and $3.3 \mathrm{MgCl}_{2}$. After $2-3 \mathrm{~min}$, the brain was then mounted to a platform using cyanoacrylate adhesive and submerged in sucrose ACSF. Coronal slices $(300 \mu \mathrm{m})$ were prepared using a vibratome (model VT1200, Leica) and then maintained in a holding chamber containing standard ACSF ( $119 \mathrm{~mm} \mathrm{NaCl}, 2.5 \mathrm{~mm} \mathrm{KCl}, 1.3 \mathrm{~mm} \mathrm{MgCl}_{2}, 2.5$ $\mathrm{mm} \mathrm{CaCl}_{2}, 1.0 \mathrm{~mm} \mathrm{Na}_{2} \mathrm{H}_{2} \mathrm{PO}_{4}, 26.2 \mathrm{~mm} \mathrm{NaHCO}_{3}, 11 \mathrm{~mm}$ glucose, equilibrated with $95 \% \mathrm{CO}_{2}, 5 \% \mathrm{O}_{2}$ ) in a Braincubator (PAYO Scientific). Slices were incubated at $32^{\circ} \mathrm{C}$ for $30 \mathrm{~min}$ then maintained at $18^{\circ} \mathrm{C}$ until recording.

For electrophysiological recordings, brain slices were transferred to a recording chamber and continuously superfused with ACSF $(2 \mathrm{ml} / \mathrm{min})$ at $30^{\circ} \mathrm{C}$. Whole-cell patch-clamp recordings were made from visually identified neurons using a microscope (Zeiss Axio Examiner D1) equipped with a $20 \times$ water-immersion objective (1.0 NA). Patch pipettes (2-5 $\mathrm{M} \Omega$ ) were filled with an internal solution containing the following (in mM): $135 \mathrm{KMeSO}_{4}, 8 \mathrm{NaCl}, 10$ HEPES, $2 \mathrm{Mg}_{2}$-ATP, $0.3 \mathrm{Na}_{3}$-GTP, 0.3 EGTA, 0.05 Alexa-594, pH 7.3, with $\mathrm{KOH}, 280-290$ mOsm. Voltage recordings were amplified using a Multiclamp 700B amplifier (Molecular Devices), filtered at $6 \mathrm{kHz}$, digitized at $20 \mathrm{kHz}$ with a Digidata $1440 \mathrm{~A}$ (Molecular Devices) interface, and controlled using AxoGraph (Axograph). eNpHR was activated by $535 \mathrm{~nm}$ light using an LED fluorescence illumination system ( $\mathrm{pE}-2$, CoolLED). EPSPs were evoked via a monopolar stimulator fabricated from a patch pipette filled with ACSF positioned within the BLA. Stimuli were supplied by a constant voltage isolated stimulator (DS2A, Digitimer). Only cells that had resting potentials more negative than $-55 \mathrm{mV}$, action potential amplitudes $>100 \mathrm{mV}$, 
and input resistances $>60 \mathrm{~m} \Omega$ were considered healthy and included in the dataset. Projection neurons were distinguished from local circuit interneurons based on their action potential half-width $(>0.7 \mathrm{~ms})$, their relatively small fast afterhyperpolarization $(<15 \mathrm{mV})$, and their frequency-dependent spike broadening. Data were not corrected for liquid junction potentials.

\section{Baseline lever pressing}

We used conditioned suppression of lever pressing as our measure of learned fear (Yau and McNally, 2015; Sengupta et al., 2016). Rats were trained to lever press to establish a stable baseline lever pressing response. On days 1 and 2, rats received magazine training in which every lever press was rewarded with the delivery of a pellet. In addition, during magazine training sessions only, rats also received free pellet deliveries on a fixed interval $300 \mathrm{~s}$ schedule, in which a pellet was delivered on average every $300 \mathrm{~s}$. These "free" pellets were used to aid learning about the location of food delivery. Magazine training sessions were terminated after $60 \mathrm{~min}$, or if the rat reached 100 lever presses. From day 3 onwards, lever pressing was maintained on variable interval schedules. On day 3 , rats underwent a $60 \mathrm{~min}$ session of lever press training under a variable interval $30 \mathrm{~s}$ schedule. From day 4 until the end of the experiment, rats were maintained on a variable interval of $120 \mathrm{~s}$. These sessions lasted 120 min unless otherwise noted. On days 9-10, rats received preexposure to the CS to be used in the experiment during a $120 \mathrm{~min}$ preexposure session. Rats were habituated to the tethering procedure for $4 \mathrm{~d}$ on days $7-10$.

\section{Fiber photometry}

Rats underwent fear conditioning on days 11-13 where they received differential fear conditioning to two CS. One CS $\left(\mathrm{CS}^{+}\right.$: a 60 s flashing $2 \mathrm{~Hz}$ LED light or a $60 \mathrm{~s} 80 \mathrm{~dB}$ clicker, counterbalanced) was paired four times with a $0.6 \mathrm{~mA}, 0.5 \mathrm{~s}$ footshock, whereas the other CS $\left(\mathrm{CS}^{-}: \mathrm{a} 60 \mathrm{~s}\right.$ flashing $2 \mathrm{~Hz}$ LED light or a $60 \mathrm{~s} 80 \mathrm{~dB}$ clicker, counterbalanced) was not. The trials were presented in a pseudorandom order with an intertrial interval (ITI) of 1200 to $1800 \mathrm{~s}$.

Recordings were completed using Fiber Photometry Systems from Doric Instruments and Tucker-Davis Technologies (RZ5P, Synapse). Excitation light was emitted from 465 and $405 \mathrm{~nm}$ LEDs (Doric Instruments), controlled via dual channel programmable LED drivers. These wavelengths were reflected into the $400 \mu \mathrm{m}$ prebleached patch cable via a Dual Fluorescence Mini Cube (Doric Instruments). Light intensity at the tip of the patch was set to $200-400 \mu \mathrm{W}$ and was kept constant across sessions. At the start of each recording session, patch cables were attached to the fiber optic implant and recording was initiated. Excitation light was delivered $3 \mathrm{~min}$ before each CS onset and terminated $1 \mathrm{~min}$ after each CS offset.

GCaMP6f fluorescence was collected from the same implant/patch cable. $\mathrm{Ca}^{2+}$-dependent $(525 \mathrm{~nm})$ and isobestic control $(430 \mathrm{~nm})$ fluorescence signals (corresponding to $465 \mathrm{~nm}$ and $405 \mathrm{~nm}$ excitation, respectively) were relayed to femtowatt photoreceivers (Newport, 2151) through dichroic mirrors and bandpass filters within the Fluorescence Mini Cube (Doric Instruments). Synapse software controlled and modulated excitation light $(465 \mathrm{~nm}, 220 \mathrm{~Hz} ; 405 \mathrm{~nm}, 330 \mathrm{~Hz})$ and demodulated transduced fluorescence signals in real-time ( $1 \mathrm{kHz}$ sampling rate) via the RZ5P. Synapse/RZ5P also received Med-PC signals to record behavioral events and experimenter-controlled stimuli in real time.

\section{BLA neurons and fear learning}

Rats were attached to bilateral patch cables outputting at least $9 \mathrm{~mW}$ of $625 \mathrm{~nm}$ light, measured through an unimplanted fiber optic cannula, before session commencement in this and subsequent experiments. On days $11-13$, rats underwent $120 \mathrm{~min}$ conditioning sessions where they received four presentations of $60 \mathrm{~s}$ auditory CS ( $85 \mathrm{~dB}$ clicker) coterminating with a $0.5 \mathrm{~s}, 0.6 \mathrm{~mA}$ footshock US. The $625 \mathrm{~nm}$ light delivery coincided with US presentations and extended for a further $4.5 \mathrm{~s}$ after US. There was a randomized ITI of 1200-1800 s. For the offset control, rats were trained identically to the above with the single exception that 625 $\mathrm{nm}$ light delivery occurred randomly in the ITI between CS-US pairings during conditioning. All rats were tested in a single $70 \mathrm{~min}$ session on day
14. Rats received four $60 \mathrm{~s}$ presentations of the auditory CS with an ITI of $900 \mathrm{~s}$.

\section{BLA neurons and fear extinction learning}

Rats underwent fear conditioning on days $11-13$ where they received four presentations of an auditory CS ( $85 \mathrm{~dB}$ clicker) coterminating with a $0.5 \mathrm{~s}, 0.6 \mathrm{~mA}$ footshock US. All CS were presented with a randomized ITI of $1200-1800 \mathrm{~s}$. Fear acquisition sessions were identical to the above. On days 14-16, rats were extinguished. All rats received four $60 \mathrm{~s}$ presentations of the auditory CS, which coterminated with $0.5 \mathrm{~s}$ of photoinhibition. This extended for a further $4.5 \mathrm{~s}$ beyond the CS. These stimulus events were presented with a randomized ITI of 490-1200 s. For the offset control, the same offset control rats from the acquisition experiment were trained to fear a different CS (visual CS 4 pairings a day for $3 \mathrm{~d}$ with a $0.5 \mathrm{~s}, 0.6 \mathrm{~mA}$ footshock US). They were extinguished to the CS in a manner identical to the above, with the single exception that $625 \mathrm{~nm}$ light delivery occurred randomly in the ITI between CS presentations.

Reacquisition of fear conditioning. On days 17-20, rats that underwent fear reacquisition received four presentations of the auditory CS coterminating with a $0.5 \mathrm{~s}, 0.6 \mathrm{~mA}$ footshock US in 70 min reacquisition sessions. The ITI was randomized 1200-1800 s. There was no photoinhibition.

Acquisition of appetitive conditioning. On days 17-20, rats that underwent the appetitive conditioning procedure received four presentations of the auditory CS ( $30 \mathrm{~s}$ in duration) followed by the delivery of $3 \times 45$ $\mathrm{mg}$ sucrose pellets in a $60 \mathrm{~min}$ session. The lever that had been used for conditioned suppression was retracted during these sessions. The ITI was randomized from 300-600 s. There was no photoinhibition.

\section{BLA neurons and safety learning}

For this experiment, baseline lever press training was conducted as described earlier with one exception. The house light was locked on before session commencement and remained on after termination of the session because the house light off was used as CS in this experiment. On days 9-10, all rats underwent preexposure training where they received three $60 \mathrm{~s}$ presentations of each of the following stimuli: a flashing LED, the house light turning off, an $85 \mathrm{~dB}$ clicker, and a $1800 \mathrm{~Hz}, 85 \mathrm{~dB}$ tone. Each stimulus was presented with a randomized ITI ranging from 600 to $900 \mathrm{~s}$. On days 11-15, rats received discrimination training where the aforementioned visual cues were counterbalanced as CSA and CSB, whereas the auditory cues were counterbalanced as CSX and CSY. These rats received four $60 \mathrm{~s}$ presentations of AX coterminating with a $0.5 \mathrm{~s}, 0.6 \mathrm{~mA}$ shock $\left(\mathrm{AX}^{+}\right)$and four nonreinforced presentations of $\mathrm{BX}^{-}$per day. These stimuli were presented with randomized ITIs of 600-900 s. Photoinhibition was delivered on $\mathrm{BX}^{-}$trials only, coterminating for $0.5 \mathrm{~s}$ of the $\mathrm{BX}^{-}$trial and extending for a further $4.5 \mathrm{~s}$. On days $16-17$, rats received four $60 \mathrm{~s}$ presentations of $\mathrm{Y}$ coterminating with a $0.5 \mathrm{~s}, 0.6 \mathrm{~mA}$ shock. These stimulus events were presented with a randomized ITI of $1200-1800 \mathrm{~s}$. All rats then underwent tests of summation and retardation. On day 18 , rats underwent a summation test where they received four $60 \mathrm{~s}$ presentations of the compound AY and BY, each. On days 19-21, rats underwent a retardation test where they were conditioned to B via four pairings with a $0.5 \mathrm{~s}, 0.6 \mathrm{~mA}$ shock

An eYFP-naive group was used as a control during the retardation. These rats received the same lever press training but then received simple $\mathrm{AX}^{+} / \mathrm{B}^{-}$discrimination training. All other behavioral procedures remained the same.

\section{BLA neurons and CS preexposure}

Rats underwent fear conditioning training on days 11-14 where they received two presentations of visual CSA (flashing LED) coterminating with a $0.5 \mathrm{~s}, 0.6 \mathrm{~mA}$ footshock US and four presentations of an auditory CSX ( $85 \mathrm{~dB}$ clicker) coterminating with photoinhibition at $0.5 \mathrm{~s}$ and extending for a further $4.5 \mathrm{~s}$. All CS were presented with a randomized ITI of 600-900 s. These training sessions lasted $120 \mathrm{~min}$. On days 15-16, all rats received two $60 \mathrm{~s}$ presentations of a compound CSAX and two presentations of CSA per session, in a counterbalanced order, with a randomized ITI of 490-1200 s. This session lasted $70 \mathrm{~min}$. On days 17-19, all rats received four presentations of CSX per session with a randomized ITI of 1200-1800 s. Each presentation of CSX coterminated with a $0.5 \mathrm{~s}$, $0.6 \mathrm{~mA}$ foot-shock US. This session lasted $120 \mathrm{~min}$. 


\section{Histology}

Cannula and viral placements were verified at the end of behavioral procedures. Following transcardial perfusion with $0.9 \%$ saline, $1 \%$ sodium nitrite solution, and $360 \mu \mathrm{l} / \mathrm{L}$ heparin, then $4 \%$ buffered PFA, brains were postfixed and then placed in $20 \%$ hypertonic sucrose solution for $24-48 \mathrm{~h}$. A cryostat (Leica Microsystems) was used to collect 40 $\mu \mathrm{m}$ coronal sections, preserved in phosphate-buffered azide $(0.1 \%$ sodium azide) at $4^{\circ} \mathrm{C}$ before immunohistochemistry. eYFP labeling used single-color peroxidase immunohistochemistry.

Free floating sections were washed for $30 \mathrm{~min}$ in $0.1 \mathrm{M}$ phosphate buffer (PB; pH 7.4), followed by $50 \%$ ethanol for $30 \mathrm{~min}$ and then $3 \%$ hydrogen peroxide diluted in $50 \%$ ethanol for $30 \mathrm{~min}$. Sections were blocked (30 min with 5\% normal horse serum (NHS) diluted in PB), then placed in 1:2000 chicken anti-GFP (Invitrogen; A10262) diluted in $0.3 \%$ Triton-X, $2 \%$ NHS, and $0.1 \mathrm{M} \mathrm{PB}, \mathrm{pH} 7.4$, and incubated at $4{ }^{\circ} \mathrm{C}$ for $48 \mathrm{~h}$. Sections were washed three times for 20 min each (PB, pH 7.4), incubated in 1:3000 biotinylated donkey anti-chicken (Jackson ImmunoResearch Laboratories; 703065 155) (diluted in a solution of $0.3 \%$ Triton-X, 2\% NHS, and $0.1 \mathrm{M} \mathrm{PB}, \mathrm{pH} 7.4$ ), overnight at room temperature. They were then washed in $\mathrm{PB}, \mathrm{pH} 7.4$, and incubated in avidinbiotin (ABC reagent; Vector Elite kit $6 \mu \mathrm{l} / \mathrm{ml}$ avidin and $6 \mu \mathrm{l} / \mathrm{ml}$ biotin) diluted with PB containing $0.2 \%$ Triton, $\mathrm{pH}$ 7.4. eYFP-IR was identified using a DAB (D5637-56, Sigma) reaction. Immediately before this, sections were washed twice in $\mathrm{PB}, \mathrm{pH} 7.4$, and once in $0.1 \mathrm{M}$ acetate buffer, $\mathrm{pH}$ 6.0. Sections were incubated in DAB solution (0.025\% DAB, $0.04 \%$ ammonium chloride, and $0.2 \%$ D-glucose in $0.1 \mathrm{~m}$ acetate buffer, $\mathrm{pH} 6.0$ ). The peroxidase reaction was catalyzed by $0.2 \mu \mathrm{l} / \mathrm{ml}$ of glucose oxidase and then were rinsed with $0.1 \mathrm{~m}$ acetate buffer. Fiber placements and extent of eYFP-IR per rat were verified and photographed using a transmitted light microscope (Olympus BX51). Only animals with fiber placements and AAV expression in basolateral amygdala were included in the analyses. A total of 28 rats were excluded due to these criteria ( 1 from photometry, 9 from fear acquisition experiment, 6 from extinction experiment, 6 from safety learning experiment, 6 from simple discrimination experiment).

\section{Quantification and statistical analyses}

Suppression ratios (SRs) were calculated as $S R=a /(a+b)$ (Annau and Kamin, 1961), where $a$ represents the number of lever presses during the CS period and $b$ represents the number of lever presses recorded $60 \mathrm{~s}$ before CS. An SR of 0.5 indicates low suppression or low fear, whereas an SR of 0 indicates complete suppression or high fear. For the appetitive conditioning procedure, a ratio of $a /(a+b)$, where $a$ represents the number of magazine entries during the CS period and $b$ represents the number of magazine entries $30 \mathrm{~s}$ before the CS, was used. In this instance, a ratio of 1 indicates exclusive entry into the magazine port during the CS, whereas a ratio of 0.5 indicates equivalent port entries during the CS and before the CS. These data were analyzed via orthogonal contrasts (Harris, 2004). The Hay's Decision-wise error rate $(\alpha)$ was controlled at 0.05 for each contrast.

For fiber photometry, event-related GCaMP6f fluorescence signals were analyzed using customized MATLAB scripts. Demodulated fluorescence signals were Gaussian filtered (to smooth each signal) and converted into a movement-corrected $\Delta \mathrm{F} / \mathrm{F}$ signal by applying a leastsquares linear fit to the $405 \mathrm{~nm}$ signal, aligning it to the $465 \mathrm{~nm}$ signal. This fitted 405 signal was used to determine the $\mathrm{Ca}^{2+}$-dependent signal as follows: $\Delta \mathrm{F} / \mathrm{F}=(465$ signal-fitted 405 signal $) /$ fitted 405 signal. For each session, $\Delta \mathrm{F} / \mathrm{F}$ signals around behavioral events (time 0 ) were isolated and aggregated; 4 to $2 \mathrm{~s}$ before each event was used as a baseline (set to $0 \%$ ) to normalize perievent $\Delta \mathrm{F} / \mathrm{F}$, the $2 \mathrm{~s}$ leading up to each event was defined as the preevent transient, and the $5 \mathrm{~s}$ following each event was defined as the event transient. Areas under the curve for event transients were calculated by approximating the integral (trapezoidal method) of the isolated normalized $\Delta \mathrm{F} / \mathrm{F}$ curves. Areas under the curve were analyzed using single-means $t$ tests against 0 .

\section{Results}

\section{BLA photoinhibition impairs fear learning}

Conditioned suppression of lever pressing for food was used to assess conditioned fear. This is a well-established measure of learned fear. It has several advantages. Suppression has a nonzero baseline because rats lever press for a pellet reward at a constant rate, so revealing decreases and increases in fear; there are high levels of activity during training and testing; it is equally sensitive to visual and auditory CS despite these CS eliciting different amounts of freezing on the same trial (Bevins and Ayres, 1991), and its assessment is completely automated.

We used fiber photometry to examine shock US-evoked activity of BLA neurons. In this and remaining experiments, we used AAVs driven from the CaMKII $\alpha$ promoter. Because this promoter preferentially, but not exclusively, results in expression in BLA CaMKII $\alpha$ principal cells, we refer to the manipulated cells as neurons rather than principal neurons. Rats received differential fear conditioning so that one $\mathrm{CS}$ ( $\mathrm{CS}^{+}$, visual or auditory) was paired with a footshock US and a second CS $\left(\mathrm{CS}^{-}\right.$, auditory or visual) was not. AAV-CaMKII $\alpha$ vectors were used to express the genetically encoded calcium $\left(\mathrm{Ca}^{2+}\right)$ indicator gCaMP6f in BLA neurons (Fig. $1 a$ ), and fiber photometry $(n=6)$ (Gunaydin et al., 2014) was used to record $\mathrm{Ca}^{2+}$ transients during the shock US.

Rats discriminated the dangerous $\mathrm{CS}^{+}$from the $\mathrm{CS}^{-}$. A suppression ratio of 0.5 indicates no fear, and a suppression ratio of 0 indicates high fear. There was selective suppression of lever pressing, indicative of learned fear to the $\mathrm{CS}^{+}$(Fig. 1b) (main effect $\mathrm{CS}^{+}{ }_{\mathrm{v}} \mathrm{CS}^{-}, F_{(1,5)}=86.84, p<0.0001$; main effect trial, $F_{(1,5)}=25.33, p=0.004$; CS $\times$ trial interaction, $F_{(1,5)}=58.97$, $p=0.001)$. The shock US evoked robust $\mathrm{Ca}^{2+}$ transients on $\mathrm{CS}^{+}$ trials that were absent on $\mathrm{CS}^{-}$trials (Fig. 1c). Area under the curve analyses for the $5 \mathrm{~s}$ following the shock US (Fig. 1d) showed increases for $\mathrm{CS}^{+}$(day 1: $t_{(22)}=2.26, p=0.03$; day $2: t_{(22)}=3.01$, $p=0.006$; day $\left.3: t_{(23)}=4.01, p=0.0005\right)$ but no changes for $\mathrm{CS}^{-}$ (day $1: t_{(23)}=-1.58, p=0.12$; day $2: t_{(23)}=-0.26, p=0.79$; day $\left.3: t_{(23)}=0.06, p=0.95\right)$, confirming robust US-evoked activity in BLA neurons during our fear conditioning preparation. We also performed a repeated-measures ANOVA to assess change in USevoked responses across days. There was main effect of trial type $\left(F_{(1,5)}=8.38, p=0.034\right)$, but no main effect of day $\left(F_{(1,5)}=3.84\right.$, $p=0.11)$ or trial $\times$ day interaction $\left(F_{(1,5)}=0.63, p=0.46\right)$, showing that there was no change in this US-evoked activity in BLA neurons across the course of conditioning.

Next, in separate animals, whole-cell patch-clamp recordings were made from eNpHR3.0-expressing BLA neurons in vitro to confirm photoinhibition. These neurons had the properties expected of BLA principal neurons (Table 1; Fig. 2a). Photoinhibition induced a rapid-onset hyperpolarization that persisted for duration of the light (Fig. $2 b ; n=7$ of 7 cells). This was sufficient to inhibit action potentials evoked by depolarizing current injections (Fig. $2 c$ ) or synaptic stimulation (Fig. 2d). Light-evoked responses were not observed in non-eNpHR3.0-expressing neurons.

To examine the impact of photoinhibition during aversive reinforcement, rats expressing AAV-CaMKII $\alpha$-eNpHR3.0-eYFP $(\mathrm{CaMKII} \alpha$-eNpHR3.0) $(n=7)$ or AAV-CaMKII $\alpha$-eYFP (CaMKII $\alpha$ eYFP) $(n=7)$ in BLA (Fig. $3 a)$ received fear conditioning to an auditory CS. They received photoinhibition during US delivery and for $4.5 \mathrm{~s}$ afterward (Fig. $3 b$ ), to encompass any activity changes persisting beyond the US. There were no differences between groups in pre-CS lever pressing rates (Table 2). Group eNpHR3.0 learned less fear than group eYFP (Fig. 3b) (main effect 
a

AAV5-CamKIl $\alpha-g C a M P 6 f$

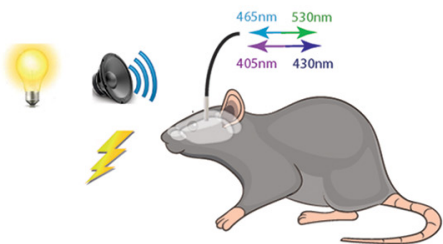

b

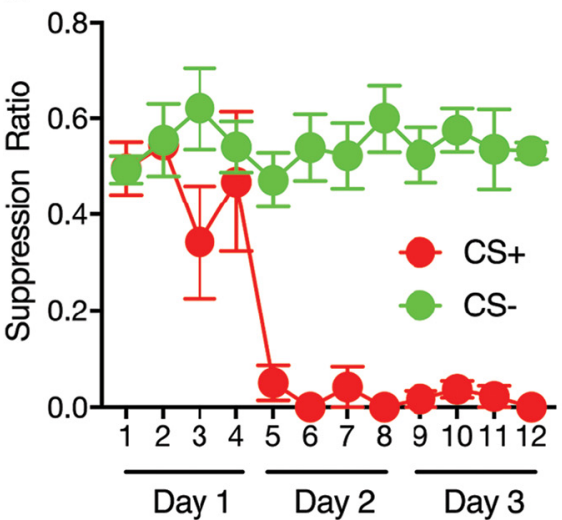

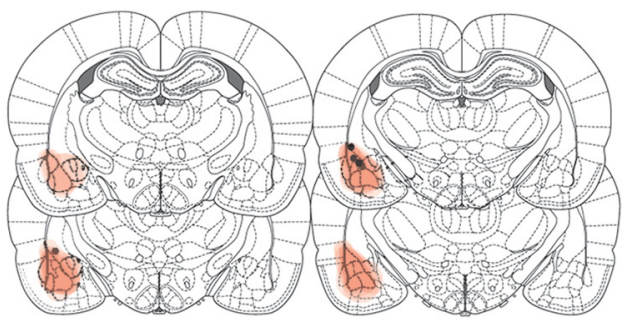

Day 1

C

shock

C onset
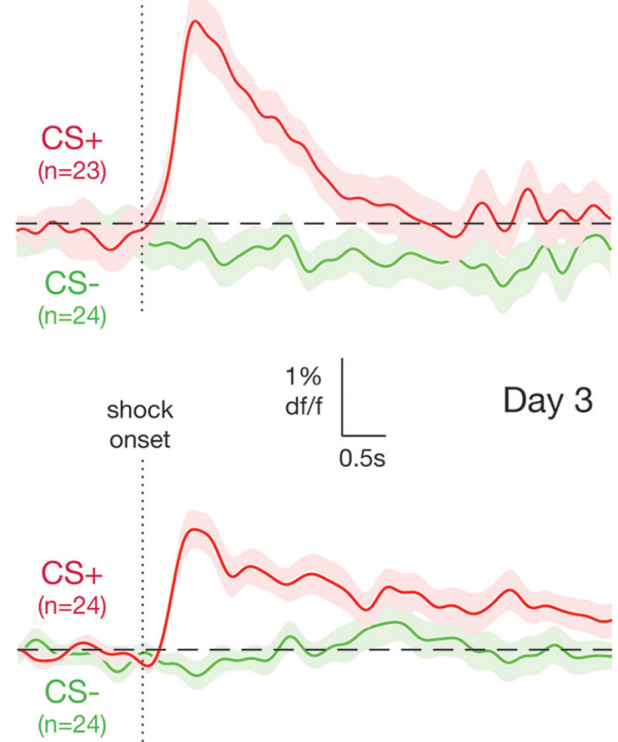

d

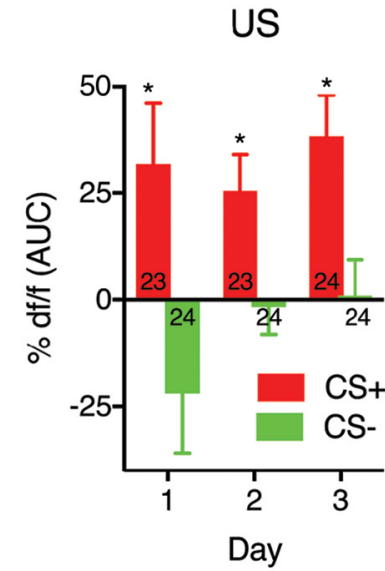

Figure 1. Fiber photometry of BLA neurons during fear learning. $\boldsymbol{a}, \mathrm{AAV}-\mathrm{CaMKIl} \alpha$-gCaMP6f was applied to BLA. AAV expression across all animals, with each rat represented at $10 \%$ opacity. Black circles represent the ventral tip of the fiber optic cannulae. $\boldsymbol{b}$, Rats received differential fear conditioning (CS ${ }^{-}$shock, $\mathrm{CS}^{+} ; \mathrm{CS}^{-}$no shock, $\mathrm{CS}^{-}$) and learned to fear $\mathrm{CS}^{+}$but not $\mathrm{CS}^{-}$. $\boldsymbol{c}, \mathrm{Ca}^{2+}$ transients during shock US delivery on $\mathrm{CS}^{+}$trials and omission on $\mathrm{CS}^{-}$trials on days 1 and 3 of conditioning. $n$ indicates number of trials. $d$, Areas under the $\Delta \mathrm{F} / \mathrm{F}$ curve for the $5 \mathrm{~s}$ from onset of shock or shock omission across conditioning. $n$ indicates number of trials. $n=6 .{ }^{*} p<.05$.

Table 1. Properties of BLA ${ }^{\text {CaMKII } \alpha}$ neurons during whole-cell patch-clamp recordings

\begin{tabular}{lcc}
\hline Property & Mean \pm SD & $n$ \\
\hline Resting membrane potential & $-69 \pm 7 \mathrm{mV}$ & 7 \\
Input resistance & $145 \pm 48 \mathrm{M} \Omega$ & 7 \\
Membrane time constants & $29 \pm 13 \mathrm{~ms}$ & 7 \\
\hline
\end{tabular}

of group, $F_{(1,12)}=4.74, p=0.05$; main effect of day, $F_{(1,12)}=294.42$, $p<0.0001$; no group $\times$ day interaction, $\left.F_{(1,12)}=4.08, p=0.06\right)$. They also expressed less fear on test $\left(F_{(1,12)}=7.89, p=0.016\right)$ (Fig. $3 b$ ), showing that photoinhibition impaired Pavlovian fear learning in conditioned suppression.

This impairment was specific to inhibition of US-evoked activity. Separate groups expressing CaMKII $\alpha$-eYFP $(n=7)$ or CaMKII $\alpha$-eNpHR3.0 $(n=5)$ in BLA (Fig. $3 c)$ received fear conditioning with photoinhibition at random times during the ITI. Again, there were no differences between groups in pre-CS lever pressing rates. There was no effect on fear learning (acquisition main effect of day, $F_{(1,10)}=90.48, p<0.0001$; no main effect of group, $F_{(1,10)}=0.049, p=0.82$; or group $\times$ day interaction, $\left.F_{(1,10)}=0.044, p=0.83\right)\left(\right.$ test: $F_{(1,10)}=0.35, p=0.56$; Fig. $3 d$ ).

\section{BLA photoinhibition augments fear loss during extinction}

Just as rats learn to fear a CS that signals shock, so too do they learn to reduce fear to that CS when it is presented in the absence of shock during extinction training. We asked whether BLA photoinhibition during nonreinforcement would affect fear extinction learning. Rats expressing CaMKII $\alpha$-eYFP $(n=14)$ or CaMKII $\alpha$-eNpHR3.0 $(n=11)$ in BLA (Fig. $4 a-c)$ received fear conditioning to an auditory CS followed by extinction training involving CS alone presentations and photoinhibition at the time of the expected but absent footshock US.

Photoinhibition during extinction training augmented loss of conditioned fear (Fig. 4d). Group eNpHR3.0 showed significantly less fear than group eYFP (main effect of group, $F_{(1,23)}=$ $12.37, p=0.002$ ), and fear decreased across the days of extinction (main effect of day, $F_{(1,23)}=107.73, p<0.0001$; no group $\times$ day interaction, $\left.F_{(1,23)}=0.91, p=0.35\right)$. This augmentation of fear loss was temporally specific. Photoinhibition during the extinction ITI (Fig. $4 f$ ) in separate groups (eNpHR3.0, $n=5$; eYFP $n=$ 7 ) had no effect (main effect of trial, $F_{(1,10)}=36.34, p<0.0001$; no main effect of group, $F_{(1,10)}=0.27, p=0.61$; and no interaction, $F_{(1,10)}=0.01, p=0.92$ ) (Fig. $4 g$ ).

Manipulations that augment extinction can produce resistance to fear relapse (Leung and Westbrook, 2008; Leung et al., 2012). To examine whether the augmented loss of fear here was accompanied by resistance to relapse, rats that had received extinction training + photoinhibition (Fig. $4 d$ ) were divided into four groups. Two groups (eYFP, $n=6$; or eNpHR3.0, $n=5$ ) received fear (aversive) reacquisition training so that they again received pairings of the extinguished CS with the shock US (Fig. 4e). There was no photoinhibition during reacquisition. The groups did not differ on the last trial of extinction training $\left(F_{(1,9)}=1.92, p=0.19\right)$ or on the first 
a

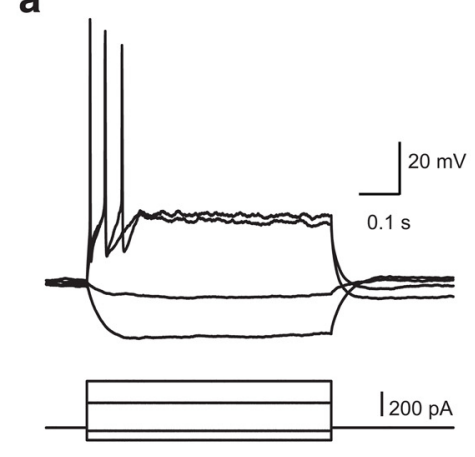

b

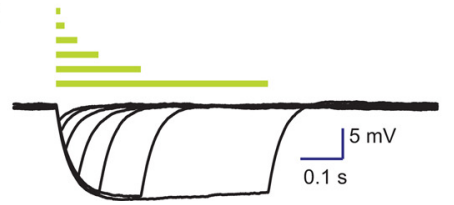

C
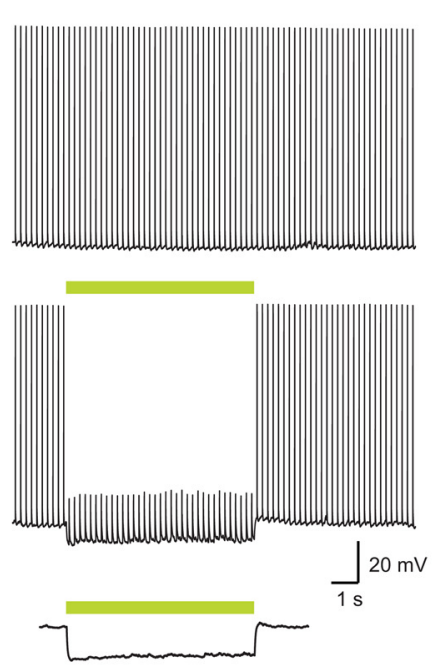

d

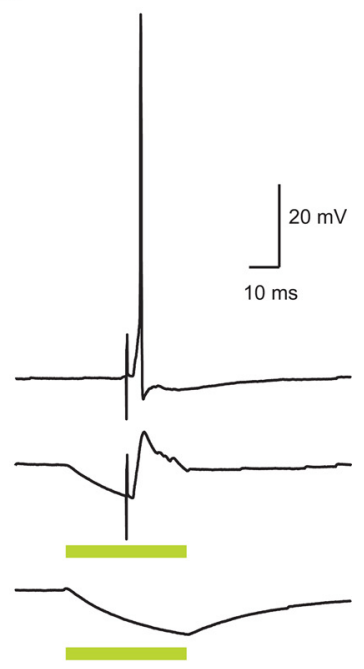

Figure 2. Characterization of BLA neurons. $\boldsymbol{a}$, Typical voltage response of eNpHR3.0-positive neurons to positive and negative current injections. $\boldsymbol{b}$, Voltage responses to photoinhibition of various durations. Bars represent timing of the stimuli. c, Action potential train evoked by brief current injections ( $5 \mathrm{~ms}, 10 \mathrm{~Hz}$ ) plotted above the response to a $7 \mathrm{~s} \mathrm{light} \mathrm{pulse} \mathrm{delivered} \mathrm{during} \mathrm{the} \mathrm{AP} \mathrm{train,}$ and the response to a $7 \mathrm{~s}$ light pulse in the absence of depolarizing current injections. $\boldsymbol{d}$, Response to synaptic stimulation (top), synaptic stimulation during photoinhibition (middle), and photoinhibition alone (bottom). $n=7$ cells.

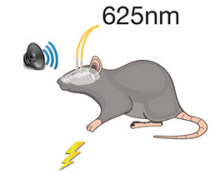

Acquisition

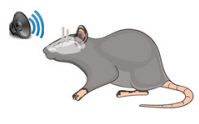

Test $\mathbf{a}$

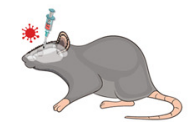

AAV5-CamKIl $\alpha-e N p H R 3.0$ AAV5-CamKIll-eYFP

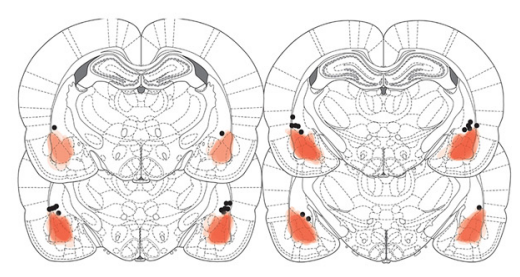

C

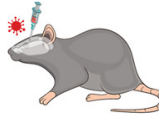

AAV5-CamKIll $\alpha$-eNpHR3.0 AAV5-CamKIll-eYFP

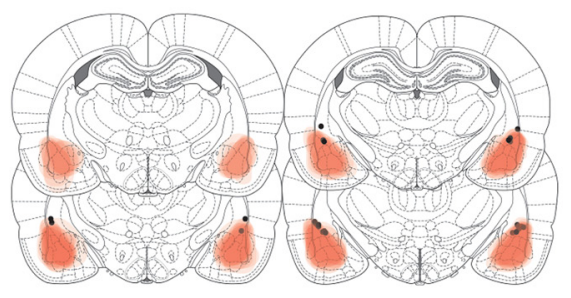

b

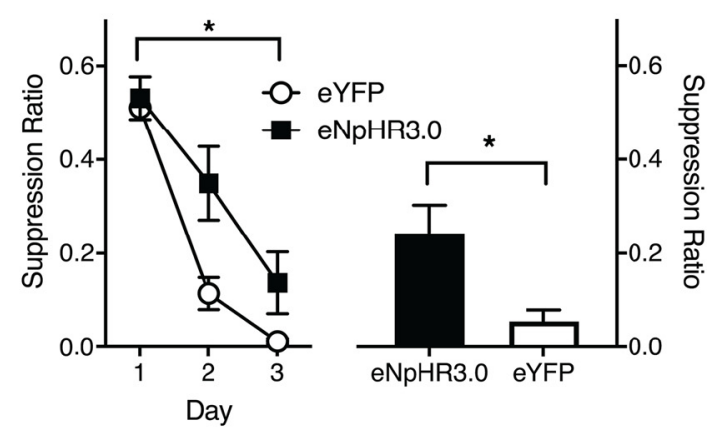

d

Acquisition Offset

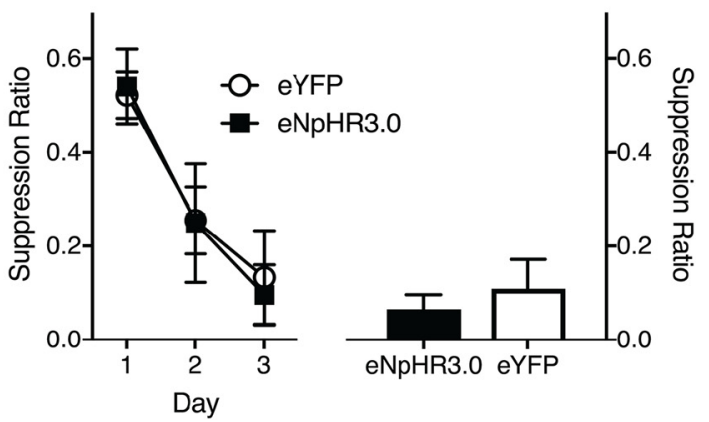

Figure 3. BLA neurons and fear learning. $\boldsymbol{a}$, AAV expression across all animals, with each rat represented at $10 \%$ opacity. Black circles represent the ventral tip of the fiber optic cannulae. $\boldsymbol{b}$, eYFP and eNpHR3.0 groups received $\mathrm{CS}^{-}$shock pairings with photoinhibition during the shock US. Photoinhibition impaired fear conditioning. A suppression ratio of 0.5 indicates no fear, and a suppression ratio of 0 indicates high fear. c, AAV expression across offset control animals, with each rat represented at $10 \%$ opacity. $d$, Control eYFP and eNpHr 3.0 groups received CS ${ }^{-}$shock pairings and photoinhibition randomly during the ITI. Data are mean \pm SEM. Group sizes were as follows: eYFP, $n=7$; eNpHR3.0, $n=7$; eYFP-Offset, $n=7$; eNpHR3.0-0ffset, $n=5 .{ }^{*} p<0.05$. 
Table 2. Mean \pm SEM pre-CS lever press rates for each group in each experiment

\begin{tabular}{|c|c|c|c|c|c|c|c|c|c|c|c|c|c|c|c|c|}
\hline Experiment & \multicolumn{4}{|c|}{ Acquisition } & & & & & & & & & & & & \\
\hline \multirow{4}{*}{ Photometry } & & 1 & 2 & 3 & & & & & & & & & & & & \\
\hline & $\mathrm{A}^{+}$ & $10.5(2.43)$ & $\begin{array}{l}11.33 \\
(1.80)\end{array}$ & $\begin{array}{l}10.67 \\
(0.92)\end{array}$ & & & & & & & & & & & & \\
\hline & B- & $7.67(0.56)$ & $\begin{array}{l}12.5 \\
(0.67) \\
\end{array}$ & $\begin{array}{c}10 \\
(1.71)\end{array}$ & & & & & & & & & & & & \\
\hline & \multicolumn{4}{|c|}{ Acquisition } & \multicolumn{2}{|c|}{ Test } & & & & & & & & & & \\
\hline \multicolumn{2}{|l|}{ Acquisition } & 1 & 2 & 3 & & & & & & & & & & & & \\
\hline eNpHR & A+ & $\begin{array}{l}12.96 \\
(3.07)\end{array}$ & $\begin{array}{l}14.86 \\
(2.88)\end{array}$ & $\begin{array}{l}15.07 \\
(1.96)\end{array}$ & A & $\begin{array}{c}19.18 \\
(3)\end{array}$ & & & & & & & & & & \\
\hline eYFP & $\mathrm{A}^{+}$ & $15.5(1.83)$ & $\begin{array}{l}14.39 \\
(2.71) \\
\end{array}$ & $\begin{array}{l}16.79 \\
(1.50)\end{array}$ & A & $\begin{array}{l}17.04 \\
(1.25)\end{array}$ & & & & & & & & & & \\
\hline & \multicolumn{2}{|c|}{ Acquisition } & \multicolumn{4}{|c|}{ Extinction } & \multicolumn{5}{|c|}{ Aversive Reacquisition } & \multicolumn{5}{|c|}{ Appetitive Acquisition } \\
\hline Extinction & & & & 1 & 2 & 3 & Day & 1 & 2 & 3 & 4 & Day & 1 & 2 & 3 & 4 \\
\hline eNpHR & $\mathrm{A}^{+}$ & $29.3(2.15)$ & A & $\begin{array}{c}1 \\
15.5 \\
(2.13)\end{array}$ & $\begin{array}{c}2 \\
16 \\
(0.49)\end{array}$ & $\begin{array}{c} \\
17.8 \\
(3.15)\end{array}$ & $\frac{A^{+}}{\mathrm{Aay}}$ & $\begin{array}{c}1 \\
23 \\
(4.04)\end{array}$ & $\begin{array}{c}23 \\
23.9 \\
(5.01)\end{array}$ & $\begin{array}{c}3 \\
21.7 \\
(0.76)\end{array}$ & $\begin{array}{c}4 \\
17.8 \\
(2.16)\end{array}$ & $\begin{array}{l}\text { Day } \\
\text { Mag }\end{array}$ & $\begin{array}{c}1 \\
1.92 \\
(0.78)\end{array}$ & $\begin{array}{c}2 \\
2.38 \\
(1.56)\end{array}$ & $\begin{array}{c}3.42 \\
(1.34) \\
\end{array}$ & $\begin{array}{c}4 \\
3.46 \\
(3.22)\end{array}$ \\
\hline eYFP & $\mathrm{A}^{+}$ & $\begin{array}{l}15.45 \\
(3.13)\end{array}$ & A & $\begin{array}{c}10.4 \\
(1.80)\end{array}$ & $\begin{array}{l}10.9 \\
(2.75)\end{array}$ & $\begin{array}{c}12.1 \\
(1.95)\end{array}$ & $\mathrm{A}^{+}$ & $\begin{array}{l}14.65 \\
(4.06)\end{array}$ & $\begin{array}{c}15 \\
(3.20) \\
\end{array}$ & $\begin{array}{c}17.5 \\
(3.16) \\
\end{array}$ & $\begin{array}{l}15.05 \\
(3.75)\end{array}$ & Mag & $\begin{array}{c}1.59 \\
(0.57)\end{array}$ & $\begin{array}{c}1.25 \\
(0.34)\end{array}$ & $\begin{array}{l}2.03 \\
(0.63)\end{array}$ & $\begin{array}{l}2.59 \\
(1.48) \\
\end{array}$ \\
\hline & \multicolumn{6}{|c|}{ Discrimination } & \multicolumn{3}{|c|}{ Acquisition } & \multicolumn{2}{|c|}{ Summation } & \multicolumn{4}{|c|}{ Retardation } & \\
\hline$\frac{\text { Conditioned }}{\text { inhibition }}$ & & 1 & 2 & 3 & 4 & 5 & & 1 & 2 & & & & 1 & 2 & 3 & \\
\hline \multirow[t]{2}{*}{$\mathrm{eNpHR}$} & $\mathrm{AX+}$ & $7.38(1.18)$ & $\begin{array}{l}9.67 \\
(3.31)\end{array}$ & $\begin{array}{c}7.33 \\
(1.08) \\
\end{array}$ & $\begin{array}{l}8.17 \\
(2.10) \\
\end{array}$ & $\begin{array}{c}7.38 \\
(1.88)\end{array}$ & \multirow[t]{2}{*}{$\mathrm{Y}+$} & \multirow[t]{2}{*}{$\begin{array}{c}9.67 \\
(0.89)\end{array}$} & \multirow[t]{2}{*}{$\begin{array}{l}10.33 \\
(2.09)\end{array}$} & AY & $\begin{array}{c}8.63 \\
(1.00)\end{array}$ & \multirow[t]{2}{*}{ B } & \multirow[t]{2}{*}{$\begin{array}{c}8.96 \\
(2.47)\end{array}$} & \multirow[t]{2}{*}{$\begin{array}{c}9.25 \\
(1.17)\end{array}$} & \multirow[t]{2}{*}{$\begin{array}{c}7.13 \\
(1.77)\end{array}$} & \\
\hline & BX- & $6.67(1.90)$ & $\begin{array}{l}7.63 \\
(0.82) \\
\end{array}$ & $7(1.72)$ & $\begin{array}{c}9.54 \\
(1.46)\end{array}$ & $\begin{array}{c}6.96 \\
(1.87)\end{array}$ & & & & BY & $\begin{array}{c}7.29 \\
(0.67)\end{array}$ & & & & & \\
\hline \multirow[t]{2}{*}{ eYFP } & $\mathrm{AX}+$ & $\begin{array}{l}11.54 \\
(2.94)\end{array}$ & $\begin{array}{c}9.82 \\
(2.74)\end{array}$ & $\begin{array}{l}10.92 \\
(1.13)\end{array}$ & $\begin{array}{c}9.82 \\
(1.62)\end{array}$ & $\begin{array}{c}12 \\
(2.42)\end{array}$ & \multirow[t]{2}{*}{$\mathrm{Y}+$} & \multirow[t]{2}{*}{$\begin{array}{l}14.11 \\
(2.95)\end{array}$} & \multirow[t]{2}{*}{$\begin{array}{l}14.14 \\
(2.55)\end{array}$} & AY & $\begin{array}{l}10.04 \\
(2.49)\end{array}$ & \multirow[t]{2}{*}{ B } & \multirow[t]{2}{*}{$\begin{array}{l}9.18 \\
(2.07)\end{array}$} & $\begin{array}{l}11.86 \\
(2.58)\end{array}$ & $\begin{array}{l}12.07 \\
(1.56)\end{array}$ & \\
\hline & $\mathrm{BX}-$ & $9.25(2.00)$ & $\begin{array}{l}8.32 \\
(1.19) \\
\end{array}$ & $\begin{array}{l}11.57 \\
(2.24) \\
\end{array}$ & $\begin{array}{l}10.29 \\
(0.78)\end{array}$ & $\begin{array}{l}11.93 \\
(0.81)\end{array}$ & & & & BY & $\begin{array}{c}9.36 \\
(1.97)\end{array}$ & & & & & \\
\hline eYFP naive & & & & & & & & & & & & B & $\begin{array}{c}8.5 \\
(1.60) \\
\end{array}$ & $\begin{array}{c}7.41 \\
(1.08)\end{array}$ & $\begin{array}{l}9.33 \\
(2.51) \\
\end{array}$ & \\
\hline & & & riminati & & & Sum & tion & & & & & & & & & \\
\hline Discrimination & & 1 & 2 & 3 & 4 & & & & & & & & & & & \\
\hline eNpHR & $\mathrm{A}^{+}$ & $26.6(1.98)$ & $\begin{array}{c}17.3 \\
(3.54)\end{array}$ & $\begin{array}{c}21.4 \\
(5.66)\end{array}$ & $\begin{array}{c}22.8 \\
(5.66)\end{array}$ & A & $\begin{array}{c}28.6 \\
(3.39)\end{array}$ & & & & & & & & & \\
\hline & $\mathrm{X}-$ & $18.4(3.14)$ & $\begin{array}{l}14.35 \\
(2.20)\end{array}$ & $\begin{array}{c}20.3 \\
(5.05)\end{array}$ & $\begin{array}{l}20.6 \\
(4.06)\end{array}$ & $A X$ & $\begin{array}{c}23.4 \\
(0.85)\end{array}$ & & & & & & & & & \\
\hline eYFP & $\mathrm{A}^{+}$ & $20(12.16)$ & $\begin{array}{c}23 \\
(7.07)\end{array}$ & $\begin{array}{c}20 \\
(0.57)\end{array}$ & $\begin{array}{l}24.5 \\
(2.12)\end{array}$ & A & $\begin{array}{c}30.4 \\
(5.94)\end{array}$ & & & & & & & & & \\
\hline & $\mathrm{X}-$ & $\begin{array}{l}22.15 \\
(5.59)\end{array}$ & $\begin{array}{l}15.65 \\
(5.67)\end{array}$ & $\begin{array}{l}23.75 \\
(5.13)\end{array}$ & $\begin{array}{c}28 \\
(4.57)\end{array}$ & $A X$ & $\begin{array}{l}29.5 \\
(5.23)\end{array}$ & & & & & & & & & \\
\hline
\end{tabular}

trial of reacquisition training $\left(F_{(1,9)}=2.50, p=0.14\right)$. However, group eNpHR3.0 was retarded in fear reacquisition (main effect of day, $F_{(1,9)}=18.61, p=0.002$; main effect of group, $F_{(1,9)}=13.99$, $p=0.005$; no group $\times$ day interaction, $\left.F_{(1,9)}=0.36, p=0.56\right)$.

Resistance to relapse might have been due to a general deficit in learning about the CS after extinction. The other two groups (eYFP, $n=8$; or eNpHR3.0, $n=6$ ) that had received photoinhibition during US omission in fear extinction received Pavlovian appetitive conditioning so that the extinguished fear CS was now paired with delivery of sucrose pellets. There was no photoinhibition during this appetitive conditioning. We measured head entries into the magazine where sucrose pellets were delivered to determine CS elevation ratios, a reliable index of Pavlovian appetitive learning (Lattal, 1999). The eNpHR3.0 group was not retarded in acquisition of appetitive learning (Fig. 4e) (main effect of day, $F_{(1,12)}=19.88, p=0.0008$; no main effect of group, $F_{(1,12)}=1.77, p=0.20$; no group $\times$ day interaction, $F_{(1,12)}=$ $0.55, p=0.47)$. So, BLA optogenetic inhibition during aversive nonreinforcement enhances loss of fear during extinction and selectively impairs relearning of fear to that CS but does not impair not appetitive learning to that CS.

\section{BLA photoinhibition impairs safety learning}

If BLA optogenetic inhibition augments fear loss in an extinction paradigm, does it also augment fear reductions during safety learning? We used an $\mathrm{AX}^{+} / \mathrm{BX}^{-}$discrimination design to assess this. Rats expressing CaMKII $\alpha$-eNpHR3.0 $(n=6)$ or CaMKII $\alpha$-eYFP $(n=7)$ in BLA (Fig. $5 a)$ received fear conditioning of the compound CS AX (i.e., CSA and $\mathrm{CSX}^{+}$) and nonreinforced presentations of the compound CS BX (CSB and $\mathrm{CSX}^{-}$) (Fig. 5b). This establishes CSA as a fear CS. CSX is established as a weak fear CS because it is unreliably paired with the shock US. CSB is established as a conditioned inhibitor of fear (a learned safety signal) because it signals absence of the shock US (Wagner et al., 1968; Wagner and Rescorla, 1972; Josselyn et al., 2005; Jovanovic et al., 2012; Kazama et al., 2013). We photoinhibited during the expected but absent shock US on CS BX ${ }^{-}$trials during discrimination training only (Fig. 5b).

Both groups discriminated the dangerous AX from the safe BX (Fig. $5 b)$. There was no main effect of group $\left(F_{(1,11)}=1.93\right.$, $p=0.19)$, a main effect of stimulus $\left(F_{(1,11)}=29.76, p=0.0002\right)$, a linear trend to $\mathrm{AX}^{+}\left(F_{(1,11)}=119.20, p<0.0001\right)$, and significant quadratic trend to $\mathrm{BX}^{-}\left(F_{(1,11)}=164.24, p<0.0001\right)$. There was slower discrimination learning among eNpHR3.0 animals; day-by-day analyses of fear to $\mathrm{BX}^{-}$showed a significant difference on day $4\left(F_{(1,11)}=6.45, p=0.027\right)$.

Rats were trained to fear a new $C S, Y$, via pairings with shock (Fig. 5c). CSY would serve as a target for testing the fear inhibitory properties of CSB. Both groups learned to fear CSY at the same rate (no main effect of group, $F_{(1,11)}=0.18, p=0.67$; main effect of day, $F_{(1,11)}=32.36, p=0.0001$; no group $\times$ day interaction, $\left.F_{(1,11)}=0.21, p=0.65\right)$. This shows that there was no longlasting impact of photoinhibition on fear learning to a different CS.

The first criterion for conditioned inhibition is that CSB should reduce fear in a summation test (Rescorla, 1969) (Fig. 5d). Rats were tested with a compound comprising two fear CS (A and $\mathrm{Y}$ ) versus a compound comprising the inhibitor (B) and a fear CS (Y). There was no photoinhibition. Rats should express high levels of fear to AY because both CSA and CSY had previously been paired with shock. At issue were whether rats showed reduced fear to BY and whether this conditioned inhibition was different between the eNpHR3.0 and eYFP groups. All animals showed evidence for conditioned inhibition, less fear to BY compared with AY (main effect of stimulus, $F_{(1,11)}=91.74, p<0.0001$ ). However, conditioned inhibition (i.e., BY test), but not conditioned fear 
a

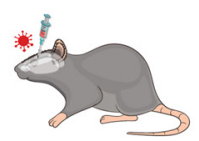

AAV5-CamKIl $\alpha-e N p H R 3.0$ AAV5-CamKIl $\alpha$-eYFP b

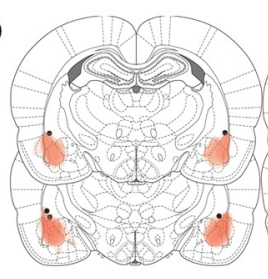

C

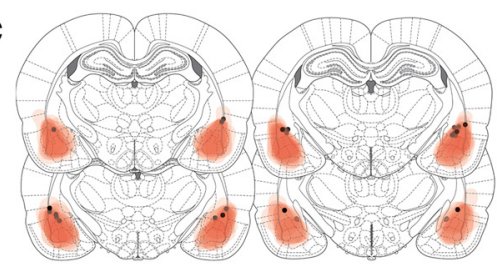

d

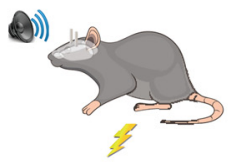

Acquisition
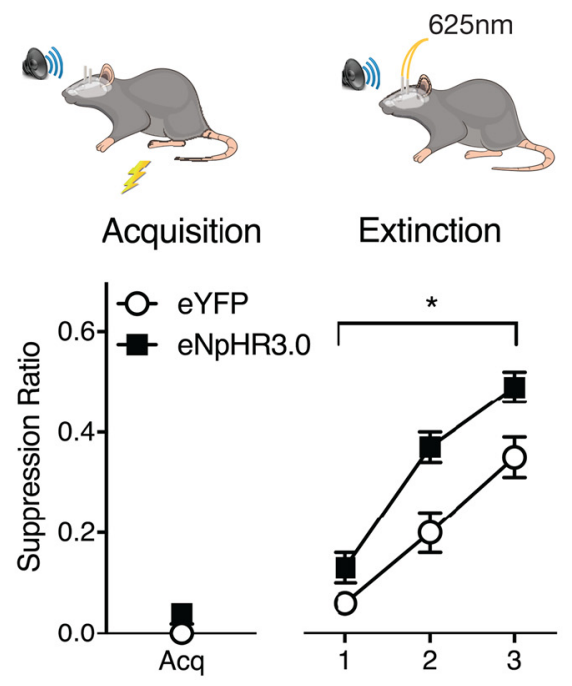

Extinction

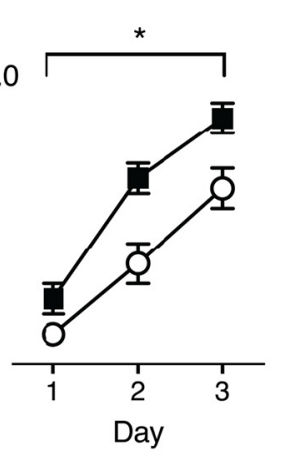

f

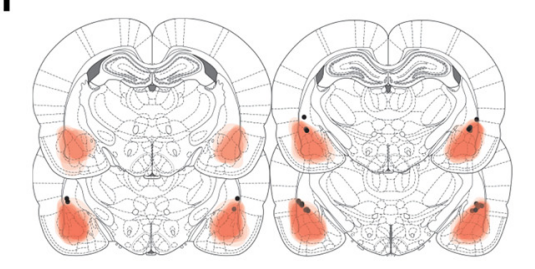

e

(3))

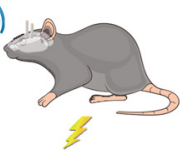

Aversive Reacquisition
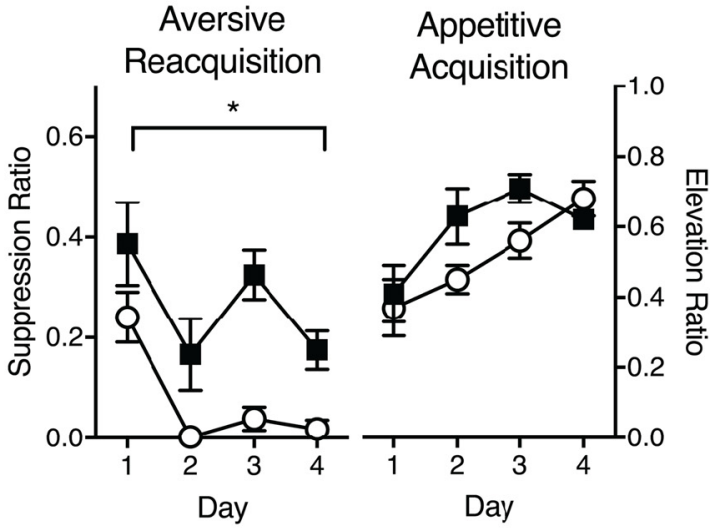

Appetitive

g

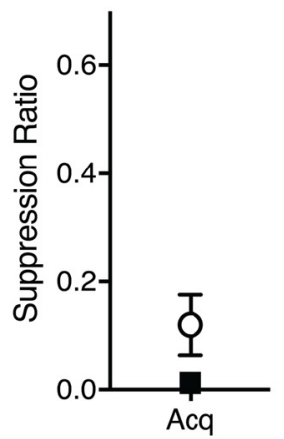

\section{Extinction Offset}

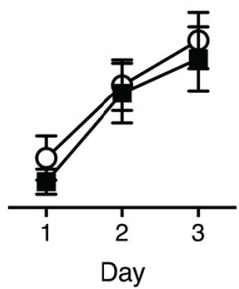

Figure 4. BLA neurons and fear extinction learning. $\boldsymbol{a}$, AAV-CaMKIl $\alpha$-eYFP or eNpHr3.0 was applied to BLA. $\boldsymbol{b}$, AAV expression for animals receiving fear conditioning, extinction, and fear reacquisition, with each rat represented at $10 \%$ opacity. Black circles represent the ventral tip of the fiber optic cannulae. $c$, AAV expression for animals receiving fear conditioning, extinction, and appetitive conditioning, with each rat represented at 10\% opacity. $\boldsymbol{d}$, eYFP $(n=14)$ and eNpHR3.0 $(n=11)$ groups received extinction training with photoinhibition during shock omission. Photoinhibition augmented fear loss during extinction. A suppression ratio of 0.5 indicates no fear, and a suppression ratio of 0 indicates high fear. $\boldsymbol{e}$, eYFP and eNpHr3.0 groups were retrained in fear or appetitive conditioning and showed selective impairments in fear relearning. For aversive conditioning, a suppression ratio of 0.5 indicates no fear, and a suppression ratio of 0 indicates high fear. For appetitive conditioning, an elevation ratio $>0.5$ indicates (S-elicited magazine entries. $f$, AAV-CaMKIll $\alpha$-eYFP or eNpHr3.0 was applied to BLA. AAV expression across all animals, with each rat represented at $10 \%$ opacity. Black circles represent the ventral tip of the fiber optic cannulae. $\boldsymbol{g}$, Control eYFP $(n=7)$ and eNpHr3.0 $(n=5)$ groups received extinction training with photoinhibition randomly during the ITI. Photoinhibition had no effect on extinction learning. Data are mean \pm SEM. ${ }^{*} p<0.05$.

(AY test), was weaker in the eNpHR3.0 groups (group $\times$ stimulus interaction, $F_{(1,11)}=5.52, p=0.039$; BY simple effect, $F_{(1,11)}=6.34$, $p=0.029$; no AY simple effect, $\left.F_{(1,11)}=0.75, p=0.40\right)$.

The second criterion for conditioned inhibition is that CSB should be slow to transform into a fear CS in a retardation test (Rescorla, 1969) (Fig. 5e). We compared fear learning with CSB among the eNpHR3.0 and eYFP groups with a control group, eYFP-naive. This control group had received $\mathrm{A}^{+} / \mathrm{B}^{-}$discrimination training, which does not establish $\mathrm{B}$ as a conditioned inhibitor, and received fear conditioning to $\mathrm{B}$ for the first time during the retardation test. They had not received photoinhibition. All groups acquired fear during the retardation test (main effect of day, $\left.F_{(1,16)}=18.88, p=0.001\right)$. CSB passed the retardation test in the eNpHR3.0 and eYFP groups compared with the eYFP-naive group $\left(F_{(1,16)}=7.70, p=0.014\right)$. However, unlike the summation test, the eYFP and eNpHR3.0 groups did not differ in retardation (no main effect of group or group $X$ day interaction for eYFP vs eNpHR3.0, $F_{(1,16)}=0.54, p=0.47$; eYFP vs eYFP naive, $F_{(1,16)}=0.04, p=0.83$; or eNpHR3.0 vs eYFP naive, $F_{(1,16)}=$ $0.84, p=0.37)$. In contrast to fear extinction, photoinhibition 
a

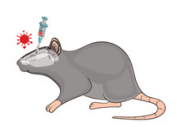

AAV5-CamKIl $\alpha$-eNpHR3.0 AAV5-CamKIl $\alpha-e Y F P$

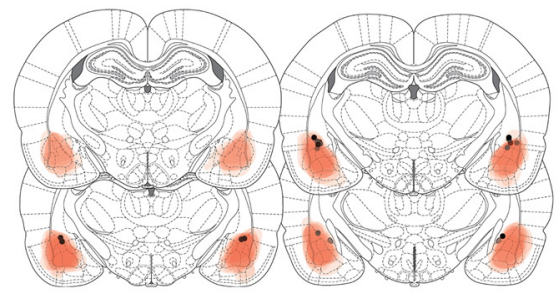

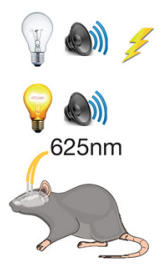

b

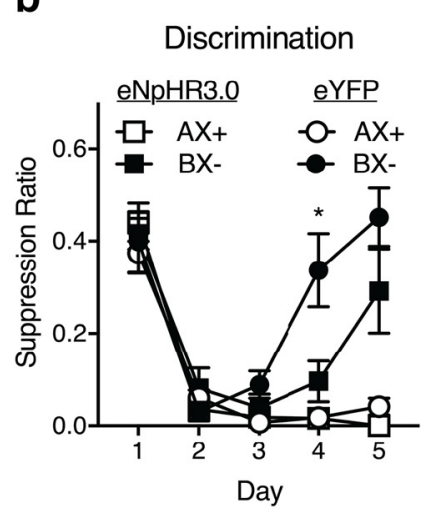

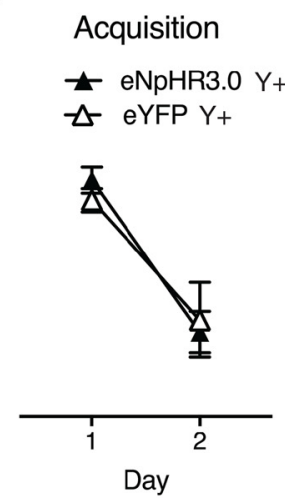
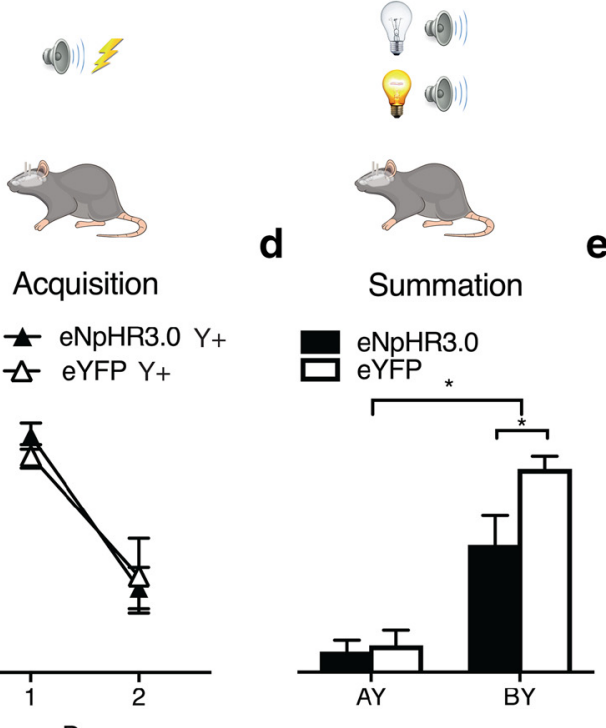

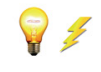

e

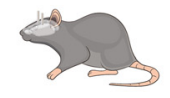

Retardation

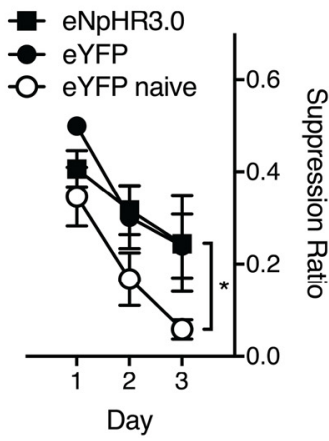

Figure 5. BLA neurons and safety learning. $a, A A V-C a M K I I \alpha$-eYFP or eNpHr3.0 was applied to BLA. AAV expression, with each rat represented at $10 \%$ opacity. Black circles represent the ventral tip of the fiber optic cannulae. $\boldsymbol{b}$, Rats received $\mathrm{AX}^{+} / \mathrm{BX}^{-}$discrimination training to establish $\mathrm{B}$ as a conditioned inhibitor of fear. Photoinhibition during US omission on $\mathrm{BX}{ }^{-}$trials slowed discrimination learning. $\boldsymbol{c}$, Rats then received $\mathrm{CS}^{+}{ }^{+}$pairings with shock. $\boldsymbol{d}$, Summation test showing poorer conditioned inhibition in the eNpHR3.0 group. $\boldsymbol{e}$, Retardation test showing normal retardation in the eNpHR3.0 group. Data are mean \pm SEM. eYFP, $n=7 ;$ eNpHR3.0, $n=6 .{ }^{*} p<0.05$.

during aversive nonreinforcement impaired conditioned inhibition learning as measured by a summation test but, like extinction, retarded later fear relearning.

\section{BLA photoinhibition does not affect simple discrimination or latent inhibition}

Simple preexposure to a CS also supports a form of inhibitory learning, latent inhibition (Lubow, 1973). Latently inhibited CS are slow to be transformed into fear CS but, unlike conditioned inhibitors, cannot reduce fear to other CS (Rescorla, 1969). We asked whether BLA photoinhibition would affect CS learning during preexposure.

Rats expressing eNpHR3.0 $(n=5)$ or eYFP $(n=5)$ in BLA (Fig. $6 a$ ) received presentations of CSA with a shock US and separate presentations of CSB alone with photoinhibition $\left(\mathrm{A}^{+} /\right.$ $\mathrm{B}^{-}$). During $\mathrm{A}^{+} / \mathrm{B}^{-}$discrimination training, there was a main effect for CSA across days (linear trend: $F_{(1,8)}=48.88, p=0.0001$ ) but no main effect of group $\left(F_{(1,8)}=0.09, p=0.77\right)$ or group $\times$ day interaction $\left(F_{(1,8)}=0.54, p=0.48\right)$ (Fig. $\left.6 b\right)$. Thus, brief photoinhibition had no effect on learning about CSB, fear learning to CSA, or simple discrimination learning. Such simple discrimination training does not normally imbue CSB with the properties of a safety signal (Rescorla and Wagner, 1972; Wagner and Rescorla, 1972), and we confirmed this by showing that CSB could not reduce fear to CSA in a summation test (no main effect of group, $F_{(1,8)}=0.001, p=0.97$; no significant difference in responding to $\mathrm{A}$ or $\mathrm{AB}, F_{(1,8)}=0.07, p=0.79$; in the eNpHR3.0 and eYFP groups, $F_{(1,8)}=0.03, p=0.61$ ) (Fig. 6c). However, preexposure to CSB should have retarded fear conditioning due to latent inhibition. This was the case (CSA from original discrimination training vs CSB, $\left.F_{(1,8)}=39.49, p=0.0002\right)$. BLA photoinhibition did not strengthen or weaken this latent inhibition (no main effect of group, $F_{(1,8)}=0.255, p=0.63$; no interaction between factors, $F_{(1,8)}=0.90, p=0.37$ ) (Fig. $6 d$ ).

\section{Discussion}

Here we isolated distinct features of fear, safety, and appetitive learning to understand the learning related roles of BLA neurons during aversive reinforcement and nonreinforcement. Photoinhibition during shock US reinforcement impaired fear learning. Photoinhibition during nonreinforcement also had effects on inhibitory learning: facilitating loss of conditioned responding during extinction, impairing relearning of fear but not learning of appetitive conditioning, and impairing learning of conditioned inhibition but not simple discrimination or latent inhibition. The most parsimonious explanation of these findings is that BLA photoinhibition disrupts CS salience.

\section{Basolateral amygdala and salience}

A primary function of the shock US or its absence during fear conditioning is to maintain CS salience (Hall and Rodríguez, 2017). Salience refers to the capacity of a stimulus to activate its internal physiological or mental representation (i.e., it is a quality of the $\mathrm{CS}$ ). The maintenance of CS salience by the US prevents habitu- 
a

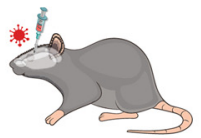

AAV5-CamKIlla-eNpHR3.0 AAV5-CamKIl $\alpha$-eYFP
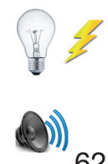

$625 \mathrm{~nm}$

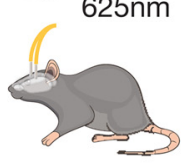

b
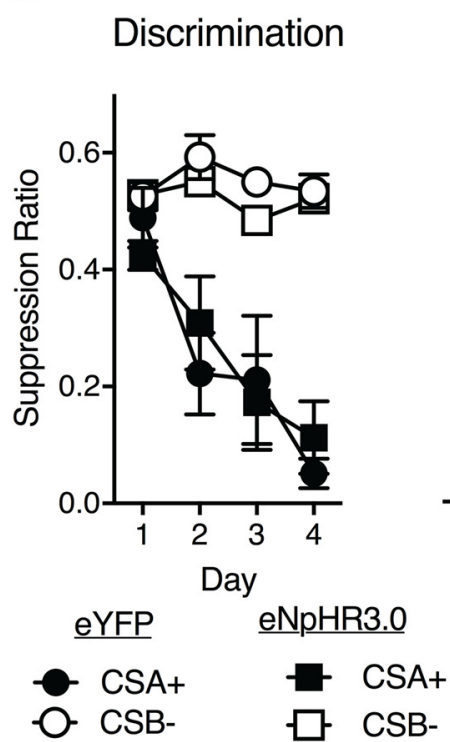
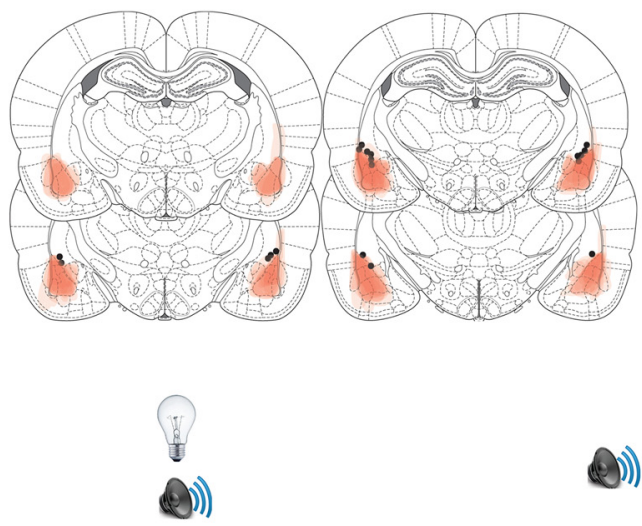

(a))

d

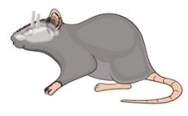

c

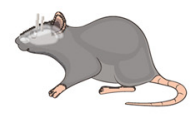

Summation

Retardation
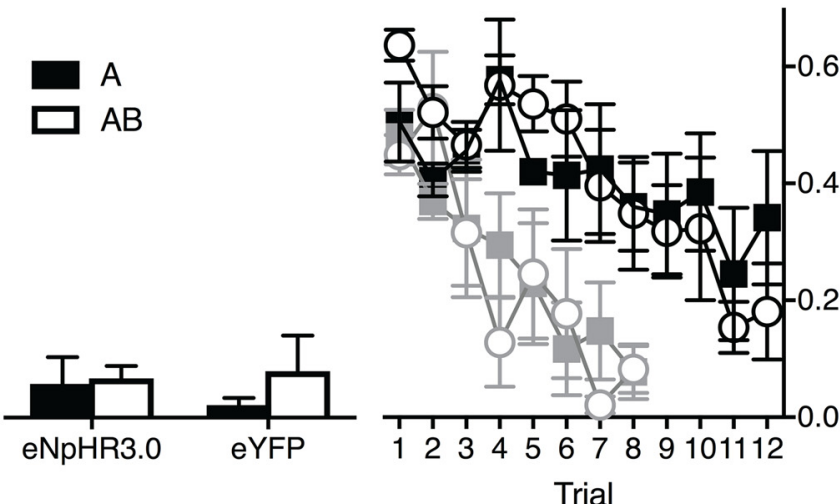

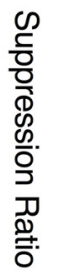

Figure 6. BLA neurons and CS preexposure. $a, A A V-C a M K I l \alpha$-eYFP or eNpHr3.0 was applied to BLA. AAV expression, with each rat represented at $10 \%$ opacity. Black circles represent the ventral tip of the fiber optic cannulae. $\boldsymbol{b}$, Rats received $A^{+} / B^{-}$discrimination training with photoinhibition on $B^{-}$trials. c, Summation test showing preexposure did not transform $B$ into a conditioned inhibitor. $\boldsymbol{d}$, Retardation test showing normal retardation in both eYFP and eNpHR3.0 groups. Data are mean \pm SEM. eYFP, $n=5$; eNpHR3.0, $n=5$.

ation to the CS during conditioning, allowing the CS to be learned about and responded to. Salience is a precursor for learning, determining the eligibility of a CS to enter into an association as well as the rate at which learning occurs. However, unlike the closely related attentional construct of associability, which refers only to the extent to which a CS can be associated with a US, salience is also necessary for stimulus control over behavior, determining the magnitude of conditioned responding. Highly salient stimuli have increased capacities to support learning and conditioned responding, whereas low salience stimuli have these capacities reduced. The deficits in learning and responding reported here are consistent with BLA photoinhibition during moments of reinforcement and nonreinforcement causing loss of CS salience.

Reductions in CS salience impair fear learning because less salient CS are poorly learned about, due to slower rates of learning, and less able to elicit conditioned responses. Interestingly, because the asymptote of learning is determined by the US, not the CS, asymptotic levels of learning could have been unaffected. Our experimental designs did not permit examination of this possibility, and it would be difficult to assess given the role of CS salience in governing the strength of conditioned responding. Reductions in CS salience will impair learning during extinction but also reduce conditioned responding during extinction because less salient CS are poor at eliciting conditioned responses. In other words, the more rapid loss of fear during extinction likely reflects deficits in behavioral control by the less salient CS rather than differences in extinction learning per se. Impaired fear relearning and responding after extinction follow from this reduction in CS salience. Impairments in safety learning occur for the same reasons. Reductions in CS salience reduce safety learning and the capacity of the safety CS to inhibit fear responses, leading to poorer performance in the summation test. Importantly, despite impairing safety learning, the same reductions in CS salience lead to slower fear learning and less fear responding during the retardation test because less salient CS are poorly learned about and less able to elicit conditioned responses.

The salience reduction had three important characteristics: it was CS-specific, long-lasting, and outcome-specific. The reduction in salience was stimulus-specific: there were no impairments 
of learning or responding to CS that were not followed by BLA photoinhibition (e.g., offset controls, control CS). Moreover, even within the same animals, there was no deficit in later fear learning to a novel CS paired with shock (Fig. 5). It was longlasting: impairments in learning and responding were detected days after last photoinhibition (e.g., retardation of fear learning following extinction or conditioned inhibition). Finally, the reductions in salience were specific to learning about or responding to CS with a predictive relationship to the presence of shock or the absence of an expected shock. There was no impairment in subsequent appetitive conditioning to the CS, even though BLA plays a critical role in appetitive learning, or in a simple CS preexposure task where the US was absent. This specificity is striking. It shows the important role of US-evoked activity in maintaining the capacity of the CS to control behavior and suggests that salience changes caused by BLA optogenetic inhibition may be outcome or motivationally specific. This supports the findings that distinct BLA circuits contribute to appetitive and aversive learning (Namburi et al., 2015; Beyeler et al., 2016).

Human anxiety disorders are associated with heightened amygdala activation to threatening stimuli (Etkin and Wager, 2007). Interestingly, the consequences of BLA photoinhibition reported here (stimulus-specific, long-lasting, and outcome-specific reductions in behavioral control) are precisely the goals of interventions for human anxiety disorders. This raises the possibility that therapeutic approaches to reduce threat stimulus salience could be especially effective in ameliorating amygdala contributions to human anxiety.

\section{Other BLA functions in fear learning}

BLA principal neurons serve a variety of other functions in fear learning, but these do not coherently account for the results reported here. Reinforcement and nonreinforcement generate a prediction error signal that instructs learning and association formation. Could the effects here be due to modulation of a Rescorla-Wagner temporal difference (Rescorla and Wagner, 1972; Sutton and Barto, 1981; Sutton, 1988) prediction error? Fear learning is instructed by positive prediction error (actual outcome of trial $>$ expected outcome), whereas fear extinction learning is instructed by negative prediction error (actual outcome $<$ expected outcome) (McNally and Westbrook, 2006; McNally et al., 2011). This error determines the strength of US inputs to the BLA (McNally et al., 2011). Interestingly, our photometry data showed no evidence, at the population level, for changes in US-evoked activity (but for one example of such decreases in single-unit activity, see Johansen et al., 2010b; for examples of increases and decreases, see Grewe et al., 2017). BLA photoinhibition could have reduced positive prediction error or augmented negative prediction error. However, conditioned inhibition depends on the same negative prediction error as extinction (Wagner and Rescorla, 1972) and should have been augmented. Instead, conditioned inhibition was impaired.

Prediction error also instructs association formation indirectly by controlling attention allocated to the CS (i.e., associability) (Pearce and Hall, 1980). CS associability is upregulated when prediction error is high and downregulated when prediction error is low. BLA photoinhibition could have reduced CS associability or prevented upregulation of associability and so reduced fear and safety learning. However, there was no effect on latent inhibition, which is due to a reduction in CS associability. Moreover, extinction learning also involves upregulation of associability because it involves a prediction error and so should have been reduced. Instead, the loss of fear during extinction was enhanced.
Together, prediction error accounts of BLA activity at the time of reinforcement and nonreinforcement are unable to explain the impact of BLA photoinhibition on fear learning.

Activity of BLA principal neurons during the post-training period aids consolidation of fear memories (Huff et al., 2013), and such consolidation processes can occur during the aftermath of each conditioning trial (Kamin, 1968; Wagner et al., 1973). However, extinction memories, like fear memories, undergo consolidation. If consolidation had been impaired, then fear extinction should have been impaired and later fear relearning enhanced. Instead, the opposite pattern of results was observed.

Finally, these effects of BLA photoinhibition cannot be due to a simple blunting of emotional reactivity. Although such a blunting could impair fear and safety learning by reducing the aversive emotional response to shock and the relief occasioned by safety, respectively, it would not lead to the long-lasting and fear-specific impairments in later learning.

These roles for BLA neurons in aversive prediction errors, memory consolidation, and other processes are likely embedded within distributed, multiplexed reinforcement signals (e.g., Roesch et al., 2010, 2012). For example, in Pavlovian appetitive conditioning, multiple neural signals can be detected in BLA during reinforcement and nonreinforcement that are well described by the actions of prediction error and its effects on CS processing (i.e., associability) and US processing (e.g., Roesch et al., 2010, 2012). Alternatively, they could involve distinct subpopulations of BLA principal neurons that might be more specifically revealed via pathway- and projection-specific imaging and manipulation. Finally, they might involve activity of the same or different neurons at different times during the conditioning trial (Livneh and $\mathrm{Paz}$, 2012; Likhtik and Paz, 2015; Sengupta et al., 2016). For example, we show here that CS salience is determined by BLA activity during US presentations. CS associability may be determined by BLA activity during CS presentations. Regardless, our data show that the primary behavioral consequence of BLA optogenetic inhibition during reinforcement and nonreinforcement across fear conditioning, fear extinction, and conditioned inhibition is a reduction in CS salience.

In conclusion, we show that brief optogenetic inhibition of BLA neurons around moments of aversive reinforcement or nonreinforcement causes reductions in the salience of conditioned stimuli, rendering these stimuli less able to be learned about and less able to control fear or safety behaviors. This reduction was stimulus-specific, long-lasting, and specific to aversive emotional states, precisely the goals of therapeutic interventions in human anxiety. Our findings identify a core learning process disrupted by BLA optogenetic inhibition. They suggest that a primary function of BLA neurons during reinforcement and nonreinforcement is to maintain the salience of conditioned stimuli that signal reinforcement or nonreinforcement. This maintenance of salience is a necessary precursor for such stimuli to gain control over fear and safety behavior.

\section{References}

Annau Z, Kamin LJ (1961) The conditioned emotional response as a function of the intensity of the US. J Comp Physiol Psychol 54:428-432. CrossRef Medline

Bevins RA, Ayres JJ (1991) Two issues in Pavlovian fear conditioning: selective fear of bright vs dark, and CS determinants of CR form. Behav Process 24:211-218. CrossRef Medline

Beyeler A, Namburi P, Glober GF, Simonnet C, Calhoon GG, Conyers GF, Luck R, Wildes CP, Tye KM (2016) Divergent routing of positive and negative information from the amygdala during memory retrieval. Neuron 90:348-361. CrossRef Medline 
Davis M (1992) The role of the amygdala in fear and anxiety. Annu Rev Neurosci 15:353-375. CrossRef Medline

Ehrlich I, Humeau Y, Grenier F, Ciocchi S, Herry C, Lüthi A (2009) Amygdala inhibitory circuits and the control of fear memory. Neuron 62:757-771. CrossRef Medline

Etkin A, Wager TD (2007) Functional neuroimaging of anxiety: a metaanalysis of emotional processing in PTSD, social anxiety disorder, and specific phobia. Am J Psychiatry 164:1476-1488. CrossRef Medline

Gore F, Schwartz EC, Brangers BC, Aladi S, Stujenske JM, Likhtik E, Russo MJ, Gordon JA, Salzman CD, Axel R (2015) Neural representations of unconditioned stimuli in basolateral amygdala mediate innate and learned responses. Cell 162:134-145. CrossRef Medline

Grewe BF, Gründemann J, Kitch LJ, Lecoq JA, Parker JG, Marshall JD, Larkin MC, Jercog PE, Grenier F, Li JZ, Lüthi A, Schnitzer MJ (2017) Neural ensemble dynamics underlying a long-term associative memory. Nature 543:670-675. CrossRef Medline

Gunaydin LA, Grosenick L, Finkelstein JC, Kauvar IV, Fenno LE, Adhikari A, Lammel S, Mirzabekov JJ, Airan RD, Zalocusky KA, Tye KM, Anikeeva P, Malenka RC, Deisseroth K (2014) Natural neural projection dynamics underlying social behavior. Cell 157:1535-1551. CrossRef Medline

Hall G, Rodríguez G (2017) Habituation and conditioning: salience change in associative learning. J Exp Psychol Anim Learn Cogn 43:48-61. CrossRef Medline

Harris RJ (2004) ANOVA: an analysis of variance primer. Itasca, IL: Peacock.

Huff ML, Miller RL, Deisseroth K, Moorman DE, LaLumiere RT (2013) Posttraining optogenetic manipulations of basolateral amygdala activity modulate consolidation of inhibitory avoidance memory in rats. Proc Natl Acad Sci U S A 110:3597-3602. CrossRef Medline

Johansen JP, Hamanaka H, Monfils MH, Behnia R, Deisseroth K, Blair HT, LeDoux JE (2010a) Optical activation of lateral amygdala pyramidal cells instructs associative fear learning. Proc Natl Acad Sci U S A 107: 12692-12967. CrossRef Medline

Johansen JP, Tarpley JW, LeDoux JE, Blair HT (2010b) Neural substrates for expectation-modulated fear learning in the amygdala and the periaqueductal gray. Nat Neurosci 13:979-986. CrossRef Medline

Johansen JP, Diaz-Mataix L, Hamanaka H, Ozawa T, Ycu E, Koivumaa J, Kumar A, Hou M, Deisseroth K, Boyden ES, LeDoux JE (2014) Hebbian and neuromodulatory mechanisms interact to trigger associative memory formation. Proc Natl Acad Sci U S A 111:5584-5592. CrossRef Medline

Josselyn SA, Falls WA, Gewirtz JC, Pistell P, Davis M (2005) The nucleus accumbens is not critically involved in mediating the effects of a safety signal on behavior. Neuropsychopharmacology 30:17-26. CrossRef Medline

Jovanovic T, Kazama A, Bachevalier J, Davis M (2012) Impaired safety signal learning may be a biomarker of PTSD. Neuropharmacology 62:695704. CrossRef Medline

Kamin LJ (1968) Attention-like processes in classical conditioning. In: Miami symposium on the prediction of behavior: aversive stimulation (Campbell BJ, Church RM, eds), pp 9-33. Miami, Florida: University of Miami.

Kazama AM, Schauder KB, McKinnon M, Bachevalier J, Davis M (2013) A novel $\mathrm{AX}^{+} / \mathrm{BX}^{-}$paradigm to assess fear learning and safety-signal processing with repeated-measure designs. J Neurosci Methods 214:177-183. CrossRef Medline

Lattal KM (1999) Trial and intertrial durations in Pavlovian conditioning: issues of learning and performance. J Exp Psychol Anim Behav Process 25:433-450. CrossRef Medline

Leung HT, Westbrook RF (2008) Spontaneous recovery of extinguished fear responses deepens their extinction: a role for error-correction mechanisms. J Exp Psychol Anim Behav Process 34:461-474. CrossRef Medline

Leung HT, Reeks LM, Westbrook RF (2012) Two ways to deepen extinction and the difference between them. J Exp Psychol Anim Behav Process 38:394406. CrossRef Medline

Likhtik E, Paz R (2015) Amygdala-prefrontal interactions in (mal)adaptive learning. Trends Neurosci 38:158-166. CrossRef Medline

Livneh U, Paz R (2012) Amygdala-prefrontal synchronization underlies resistance to extinction of aversive memories. Neuron 75:133-142. CrossRef Medline

Lubow RE (1973) Latent inhibition. Psychol Bull 79:398-407. CrossRef Medline
Lüthi A, Luscher C (2014) Pathological circuit function underlying addiction and anxiety disorders. Nat Rev Neurosci 17:1635-1643. CrossRef Medline

Marek R, Strobel C, Bredy TW, Sah P (2013) The amygdala and medial prefrontal cortex: partners in the fear circuit. J Physiol 591:2381-2391. CrossRef Medline

Maren S, Quirk GJ (2004) Neuronal signalling of fear memory. Nat Rev Neurosci 5:844-852. CrossRef Medline

McKernan MG, Shinnick-Gallagher P (1997) Fear conditioning induces a lasting potentiation of synaptic currents in vitro. Nature 390:609-611. CrossRef Medline

McNally GP, Westbrook RF (2006) Predicting danger: the nature, consequences, and neural mechanisms of predictive fear learning. Learn Mem 13:245-253. CrossRef Medline

McNally GP, Johansen JP, Blair HT (2011) Placing prediction into the fear circuit. Trends Neurosci 34:283-292. CrossRef Medline

Namburi P, Beyeler A, Yorozu S, Calhoon GG, Halbert SA, Wichmann R, Holden SS, Mertens KL, Anahtar M, Felix-Ortiz AC, Wickersham IR, Gray JM, Tye KM (2015) A circuit mechanism for differentiating positive and negative associations. Nature 520:675-678. CrossRef Medline

Paré D, Quirk GJ, LeDoux JE (2004) New vistas on amygdala networks in conditioned fear. J Neurophysiol 92:1-9. CrossRef Medline

Paxinos G, Watson C (2007) The rat brain in stereotaxic coordinates, Ed 6. Amsterdam, the Netherlands: Elsevier.

Pearce JM, Hall G (1980) A model for Pavlovian learning: variations in the effectiveness of conditioned but not of unconditioned stimuli. Psychol Rev 87:532-552. CrossRef Medline

Rescorla RA (1969) Pavlovian conditioned inhibition. Psychol Bull 72:7794. CrossRef

Rescorla RA, Wagner AR (1972) A theory of Pavlovian conditioning: variations in the effectiveness of reinforcement and nonreinforcement. In: Classical conditioning, Vol II: Current research and theory (Black AH, Prokasy WF, eds), pp 64-99. New York, NY: Appleton-Century Crofts.

Roesch MR, Calu DJ, Esber GR, Schoenbaum G (2010) Neural substrates of variations in event-processing learning in the basolateral amygdala. J Neurosci 30:2464-2471. CrossRef Medline

Roesch MR, Esber GR, Li J, Daw ND, Schoenbaum G (2012) Surprise! Neural correlates of Pearce-Hall and Rescorla-Wagner coexist within the brain. Eur J Neurosci 35:1190-1200. CrossRef Medline

Sah P, Faber ES, Lopez De Armentia M, Power J (2003) The amygdaloid complex: anatomy and physiology. Physiol Rev 83:803-834. CrossRef Medline

Schafe GE, Nader K, Blair HT, LeDoux JE (2001) Memory consolidation of Pavlovian fear conditioning: a cellular and molecular perspective. Trends Neurosci 24:540-546. CrossRef Medline

Sengupta A, Winters B, Bagley EE, McNally GP (2016) Disrupted prediction error links excessive amygdala activation to excessive fear. J Neurosci 36:385-395. CrossRef Medline

Sutton RS (1988) Learning to predict by the methods of temporal differences. Machine Learning 3:9-44. CrossRef

Sutton RS, Barto AG (1981) Toward a modern theory of adaptive networks: expectation and prediction. Psychol Rev 88:135-170. CrossRef Medline

Tovote P, Fadok JP, Lüthi A (2015) Neuronal circuits for fear and anxiety. Nat Rev Neurosci 16:317-331. CrossRef Medline

Wagner AR, Logan FA, Haberlandt K, Price T (1968) Stimulus selection in animal discrimination learning. J Exp Psychol 76:171-180. CrossRef Medline

Wagner AR, Rudy JW, Whitlow JW (1973) Rehearsal in animal conditioning. J Exp Psychol 97:407-426. CrossRef Medline

Wagner AR, Rescorla RA (1972) Inhibition in Pavlovian conditioning: application of a theory. In: Inhibition and learning (Halliday MS, Boakes RA, eds), pp 301-336. London, UK: Academic Press.

Wolff SB, Gründemann J, Tovote P, Krabbe S, Jacobson GA, Müller C, Herry C, Ehrlich I, Friedrich RW, Letzkus JJ, Lüthi A (2014) Amygdala interneuron subtypes control fear learning through disinhibition. Nature 509:453-458. CrossRef Medline

Yau JO, McNally GP (2015) Pharmacogenetic excitation of dorsomedial prefrontal cortex restores fear prediction error. J Neurosci 35:74-83. CrossRef Medline 